\title{
Molecular Motors with High Quantum Efficiency and Visible-Light Responsiveness: Meeting Two Challenges in One Design
}

J un Wang and Bo Durbeej

The self-archived postprint version of this journal article is available at Linköping University Institutional Repository (DiVA):

http:// urn.kb.se/ resolve?urn=urn:nbn:se:liu:diva- 153586

N.B.: When citing this work, cite the original publication.

Wang, J., Durbeej, Bo, (2019), Molecular Motors with High Quantum Efficiency and Visible-Light Responsiveness: Meeting Two Challenges in One Design, Computational and Theoretical Chemistry, 1148, 27-32. https:// doi.org/ 10.1016/j.comptc.2018.12.012

Original publication available at:

https:// doi.org/ 10.1016/j.comptc.2018.12.012

Copyright: Elsevier

http:// www.elsevier.com/

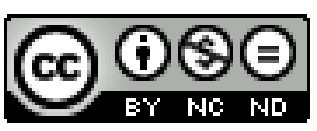




\section{Molecular motors with high quantum efficiency and visible-light}

responsiveness: Meeting two challenges in one design

Jun Wang, Bo Durbeej*

Division of Theoretical Chemistry, IFM, Linköping University, SE-581 83 Linköping, Sweden

* Corresponding author.

E-mail address: bodur@ifm.liu.se (B. Durbeej). 


\begin{abstract}
The development of light-driven rotary molecular motors is guided by a number of key goals regarding performance and applicability. While a variety of approaches to achieve high quantum yields for small UV-driven motors have been discovered, such as incorporating a protonated or alkylated nitrogen Schiff base, less progress has been made toward the goal to power molecular motors with nondestructive visible light, which will facilitate their future usage in radiationsensitive environments. Here, we present non-adiabatic molecular dynamics simulations based on multiconfigurational quantum chemistry to demonstrate that Schiff-base motors can maintain high quantum yields also when their conjugated systems are sufficiently large for them to rather be driven by visible light. In particular, we show that a visible-light responsive Schiff-base motor featuring dihydropyridinium and cyclopentenylidene motifs achieves quantum yields of almost $70 \%$ for each of the two photoisomerizations that underlie its rotary motion.
\end{abstract}

\title{
Keywords
}

Molecular devices • Rotary motion • Quantum yield • Visible light • Molecular dynamics 


\section{Graphical abstract}

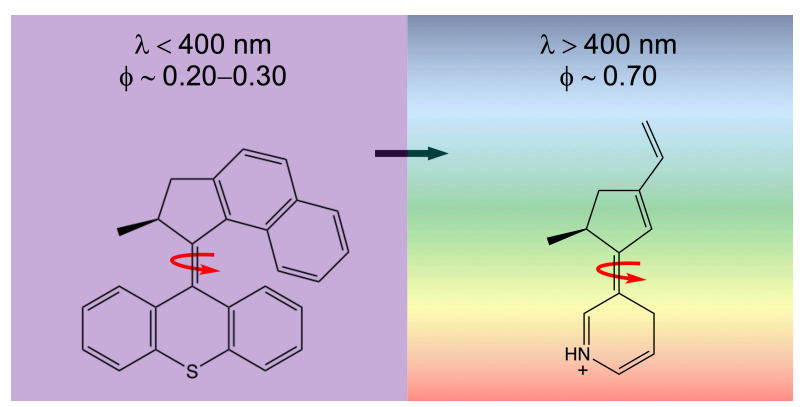

\section{Highlights}

- Design of an efficient rotary molecular motor powered by visible light

- Prediction of quantum yields through non-adiabatic molecular dynamics simulations

- Realization of fast light-driven rotary motion without intermediary thermal steps 


\section{Introduction}

The most developed class of synthetic light-driven rotary molecular motors available today are the chiral overcrowded alkenes first introduced in the late 1990s by Feringa and co-workers [1]. Fueled by both light energy and heat, these motors produce $360^{\circ}$ unidirectional rotary motion around a carbon-carbon double bond in a process that involves $E \rightarrow Z$ and $Z \rightarrow E$ photoisomerization steps as well as intermediary thermal conformational relaxation steps [2]. The unidirectionality of the rotary motion comes about by the fact that molecular chirality and steric hindrance favor the same spatial direction for each of the two photoisomerizations. Although it has been amply demonstrated that the mechanical motion produced by overcrowdedalkene motors can be exploited for a wide variety of applications in nanotechnology and medicine [3-9], there is a continued interest in improving the performance [10-23] and applicability [24-29] of these systems and in developing alternative motor designs with advantages over overcrowded alkenes in these two respects [30-41].

Regarding performance, the rotational frequencies that can be achieved by overcrowdedalkene motors under ambient conditions are limited by the free-energy barriers of the thermal steps and the quantum yields (QYs) of the photoisomerizations $[12,16,18,42,43]$. As for the thermal steps, many successful ways to accelerate these processes have been reported [1015,17,19-23], alongside the development of new motor designs that complete a full, unidirectional $360^{\circ}$ rotation from two consecutive $E \rightarrow Z$ and $Z \rightarrow E$ photoisomerizations alone (i.e., without needing intermediary thermal steps) $[30,32,34]$. As for the photoisomerization QYs, which are limited to $20-30 \%$ by the coupling of the desired torsional motion to an undesirable pyramidalization of one of the carbon atoms constituting the isomerizing bond $[16,18,42,43]$, progress has also been made toward the design of new motors whose rotary 
motion proceeds without manifestation of this effect $[36,38,39,41,43]$. For example, through quantum chemical modeling, it has been found that such pyramidalization can be curbed by motors that incorporate a protonated or alkylated nitrogen Schiff base. Owing to the electronwithdrawing capability introduced by the cationic nitrogen center, this increases the tendency of the $\pi$-bond of the isomerizing bond to cleave in such a way - heterolytically - that pyramidalization is disfavored [43]. Interestingly, this scenario has been predicted to enable Schiff-base motors to attain both higher QYs and shorter excited-state lifetimes than overcrowded-alkene motors [36,38]. Furthermore, also on computational grounds, a motor design has been proposed that even in the absence of a cationic moiety is able to photoisomerize as efficiently and quickly as Schiff-base motors, thanks to the onset of aromaticity in the photoactive excited state [39].

Regarding applicability, in turn, most overcrowded-alkene motors are driven by energetic UV light, whose high energy content is damaging to the motors and the environments in which they are operated. Therefore, in order to facilitate their usage in biological systems and other soft materials [44], making light-driven molecular motors responsive to visible light is a key goal in this field of research $[26,28,29,33,40,45,46]$. However, the progress toward this goal has been slower than that toward better-performing motors, with a few notable exceptions. For example, already in 2003, it was found that one particular overcrowded-alkene motor can be made operable by visible light through the introduction of push-pull substituents [24]. More recently, other strategies to allow overcrowded-alkene motors to be driven by visible light that have been documented include the use of large metal complexes as photosensitizers [26,28] and the extension of the aromatic core of the motors [29]. In addition to these efforts, alternative types of motors developed in the last few years that are capable of using visible light for their function 
include the hemithioindigo-based motors of Dube and co-workers [33,40] and the camphorquinone-derived imine motors of Lehn and co-workers [32].

In our own recent computational work, we have put forth a minimal design of a visiblelight-driven molecular motor, shown as motor $\mathbf{0}$ in Fig. 1 [47]. Specifically, subjecting this design - a Schiff-base motor comprising a dihydropyridinium motif connected by an olefinic bond to a vinyl-substituted cyclohexenylidene motif - to quantum chemical calculations and non-adiabatic molecular dynamics (NAMD) simulations [48-51] in the framework of complete active space self-consistent field (CASSCF) theory [52-54], two key observations were made. First, despite containing only five conjugated double bonds, $\mathbf{0}$ can be powered by photons with energies below $3 \mathrm{eV}$, i.e., well within the visible regime [47]. Second, $\mathbf{0}$ shares many favorable features previously attributed to UV-powered Schiff-base motors, such as undergoing ultrafast $E$ $\rightarrow Z$ and $Z \rightarrow E$ photoisomerizations $[36,38]$ and producing $360^{\circ}$ unidirectional rotary motion from these processes without intermediary thermal steps [38].

However, our study [47] did not consider sufficiently many NAMD trajectories that a quantitative assessment could be made as to whether the photoisomerization QYs of $\mathbf{0}$ are high or even comparable to those previously documented for a much smaller UV-powered Schiff-base motor [38]. Indeed, performing a statistically meaningful number of CASSCF-NAMD simulations is a very demanding task when five conjugated double bonds are present. Nonetheless, it is the goal of the present work to meet this challenge, albeit for a slightly different visible-light-driven Schiff-base motor than 0. Should the simulations predict high QYs, then that would indicate that synthetically feasible $[55,56]$ Schiff-base systems are promising candidates as future molecular motors with many desirable features in terms of performance, 
efficiency and applicability. Thus, despite the computational effort required, performing these simulations seems very worthwhile.

Since the purpose of the work is to test the photochemical efficiency of any suitable visible-light-driven Schiff-base motor, rather than to deepen the previous study of $\mathbf{0}$ [47], a somewhat smaller (than $\mathbf{0}$ ) motor of this type was considered, for which the required simulations are more tractable. This motor, hereafter denoted motor $\mathbf{1}$ and whose ability to be powered by visible light is confirmed in Section 3.1, is pictured in Fig. 1. As can be seen, $\mathbf{1}$ also contains five conjugated double bonds but features a point-chiral cyclopentenylidene motif instead of an axialchiral cyclohexenylidene motif, which may alter the photochemical behavior. Furthermore, 1 lacks the bulky $\mathrm{Br}$ substituents of $\mathbf{0}$, which merely serve to prevent facile isomerization between the axially chiral enantiomers of $\mathbf{0}$ [47].

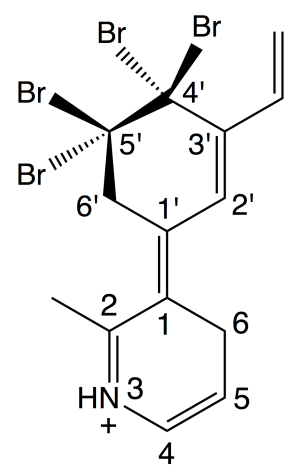

0

Recently designed

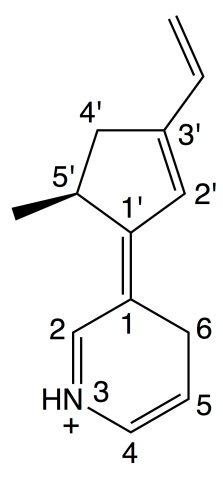

$1-E$

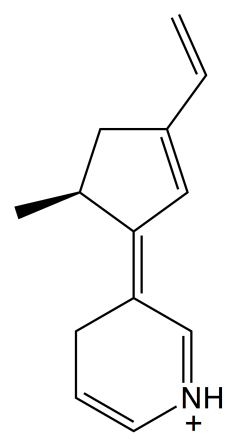

$1-Z$
Key dihedral angles for 1 :

$\theta=\mathrm{C} 2-\mathrm{C} 1-\mathrm{C} 1{ }^{\prime}-\mathrm{C} 5{ }^{\prime}$

$\theta^{\prime}=\mathrm{C} 6-\mathrm{C} 1-\mathrm{C} 1^{\prime}-\mathrm{C} 2{ }^{\prime}$

$\omega=1 / 2\left(\theta+\theta^{\prime}\right)$

$\alpha=\mathrm{C} 1-\mathrm{C} 2-\mathrm{C} 6-\mathrm{C} 1^{\prime}$

$\alpha^{\prime}=\mathrm{C}^{\prime}-\mathrm{C} 2{ }^{\prime}-\mathrm{C} 5^{\prime}-\mathrm{C} 1$

Fig. 1. Schiff-base motors driven by visible light. 


\section{Computational details}

Full computational details are given in the Supplementary material. In brief, the light absorption of $\mathbf{1}$ was investigated with complete active space second-order perturbation theory (CASPT2) [57] and the approximate coupled-cluster singles and doubles (CC2) method [58] within the resolution-of-the-identity (RI) approximation (RI-CC2) [59-61]. For these and, unless otherwise noted, all other calculations, a basis set of triple- $\xi$ quality (cc-pVTZ) was employed. The groundstate $\left(\mathrm{S}_{0}\right)$ equilibrium geometries used for the CASPT2 and RI-CC2 calculations were optimized with the CASSCF method and with second-order Møller-Plesset perturbation theory (MP2). Throughout the work, all CASSCF and CASPT2 calculations were done with an active space comprising the full $\pi$-system of $\mathbf{1}$, with 10 electrons distributed in 10 orbitals (i.e., CAS $(10,10)$ ).

Starting from the vertical Franck-Condon (FC) point in the bright and photoactive first excited singlet $\pi \pi^{*}$ state $\left(\mathrm{S}_{1}\right)$ of the respective isomer, the $E \rightarrow Z$ and $Z \rightarrow E$ photoisomerizations of 1 were modeled by performing both static minimum energy path (MEP) calculations and NAMD simulations at the CASSCF level. In both cases, a state-averaged CASSCF (SACASSCF) approach with equal weights (0.5) for $S_{0}$ and $S_{1}$ was used. Although the influence of dynamic electron correlation effects has been shown to be marginal as far as the shapes of the photoisomerization MEPs of "reference motor" $\mathbf{0}$ are concerned [47], an account of such effects were included by subjecting the MEP geometries of 1 to CASPT2 single-point calculations.

As for the NAMD simulations, for computational expedience, these were carried out with the smaller SVP basis set and were run for a maximum of 900 fs with 200 different initial nuclear configurations and velocities for each of the two isomers generated, using the JADE program [62], from a harmonic-oscillator Wigner distribution [63]. Employing an algorithm $[64,65]$ for the calculation of the non-adiabatic coupling between the $S_{1}$ and $S_{0}$ states rooted in 
Landau-Zener theory [66,67], but testing the appropriateness of this algorithm through comparison with Tully's fewest switches algorithm [68] (with a decoherence correction [69]), the trajectories were allowed to hop from the $S_{1}$ state to the $S_{0}$ state (but not from $S_{0}$ back to $S_{1}$ ) based on criteria for the energy gap and non-adiabatic coupling between the states that are given in the Supplementary material. The procedure to allow only a single hop in the simulations has been validated in a previous NAMD-based study of Schiff-base motors, albeit that that study focused on smaller UV-powered motors [38].

The calculations were done with the MOLCAS 8.0 [54], OpenMolcas 18.09 [54], Gaussian 09 [70] and TURBOMOLE 6.6 [71,72] programs. OpenMolcas 18.09 was used for NAMD simulations with Tully's fewest switches algorithm. Gaussian 09 was used for MP2 calculations. TURBOMOLE 6.6 was used for RI-MP2 and RI-CC2 calculations. MOLCAS 8.0 was used for all other calculations.

\section{Results and discussion}

\subsection{Static quantum chemical calculations}

The calculated RI-CC2 and CASPT2 excitation energies of the bright $\mathrm{S}_{1}$ state of $\mathbf{1}$ characteristic

of protonated Schiff bases [73] are given in Table 1, and are complemented by a comparison of these energies with those for the $S_{2}$ state (the second excited singlet state) in Table $S 2$ of the Supplementary material. As can be seen from Table 1, irrespective of which $\mathrm{S}_{0}$ equilibrium geometry is considered, the $S_{1}$ energies are solidly in the visible regime $(<3.1 \mathrm{eV})$, falling below or well below $3 \mathrm{eV}$. Furthermore, from Table $\mathrm{S} 2$, the $S_{1}$ state is separated from the $S_{2}$ state by more than $1.3 \mathrm{eV}$. While these results suggest that the $\mathrm{S}_{1}$ photochemistry of $\mathbf{1}$ is susceptible to be induced by visible light, it is of course important to investigate whether this photochemistry 
results in the unidirectional rotary motion that typifies light-driven rotary molecular motors [1,2]. This is the issue that we turn to next.

Table 1

Vertical RI-CC2 and CASPT2 $\mathrm{S}_{0} \rightarrow \mathrm{S}_{1}$ excitation energies of the $E$ and $Z$ isomers of 1 (in eV). ${ }^{a}$

\begin{tabular}{lcccc}
\hline & \multicolumn{2}{c}{ RI-CC2 } & \multicolumn{2}{c}{ CASPT2 } \\
\hline S $_{0}$ equilibrium geometry & $E$ isomer & $Z$ isomer & $E$ isomer & $Z$ isomer \\
\hline CASSCF/cc-pVTZ & $2.99(0.76)$ & $2.99(0.67)$ & $2.89(1.10)$ & $2.86(0.88)$ \\
MP2/cc-pVTZ & $2.82(0.73)$ & $2.86(0.71)$ & $2.69(0.87)$ & $2.77(1.01)$ \\
RI-MP2/cc-pVTZ & $2.84(0.73)$ & $2.88(0.71)$ & $2.71(0.86)$ & $2.80(1.01)$ \\
RI-MP2/SVP & $2.78(0.73)$ & $2.82(0.70)$ & $2.65(0.86)$ & $2.74(1.00)$ \\
\hline
\end{tabular}

a All calculations carried out with the cc-pVTZ basis set. Oscillator strengths in parentheses.

The calculated MEPs presented in Fig. 2 offer an unbiased description of the geometric excited-state evolution from the $\mathrm{S}_{1} \mathrm{FC}$ points of the $E$ and $Z$ isomers of $\mathbf{1}$. In particular, it is clear that absorption of visible light induces rotary motion around the central olefinic bond, as illustrated by both the molecular snapshots along the MEPs and the corresponding changes in the $\omega$ dihedral angle (defined in Fig. 1). Moreover, importantly, the direction of rotation is the same for the $E$ and $Z$ isomers, toward decreasing $\omega$ values, which is here defined as a clockwise (CW) rotation. This means that the $E \rightarrow Z$ and $Z \rightarrow E$ photoisomerizations set forth are unidirectional, as needed for $\mathbf{1}$ to function as a light-driven rotary molecular motor. Both rotations are predicted to be essentially barrierless and, by analogy with related computational studies of Schiff-base chromophores [74,75], appear to bring the systems toward conical intersection (CI) seams enabling decay to the $\mathrm{S}_{0}$ state. Given that the NAMD simulations in Section 3.2 confirm that such decay is prone to occur, we did not attempt to locate minimum-energy points on the presumed CI seams. Instead, we started CASSCF $\mathrm{S}_{0}$ geometry optimizations from the end points of the MEPs. Pleasingly, as a clear indication that consecutive $E \rightarrow Z$ and $Z \rightarrow E$ 
photoisomerizations of $\mathbf{1}$ produce a full $360^{\circ} \mathrm{CW}$ rotation without intermediary thermal steps, these optimizations yielded the $Z$ isomer as the photoproduct of the $E$ path and the $E$ isomer as the photoproduct of the $Z$ path.

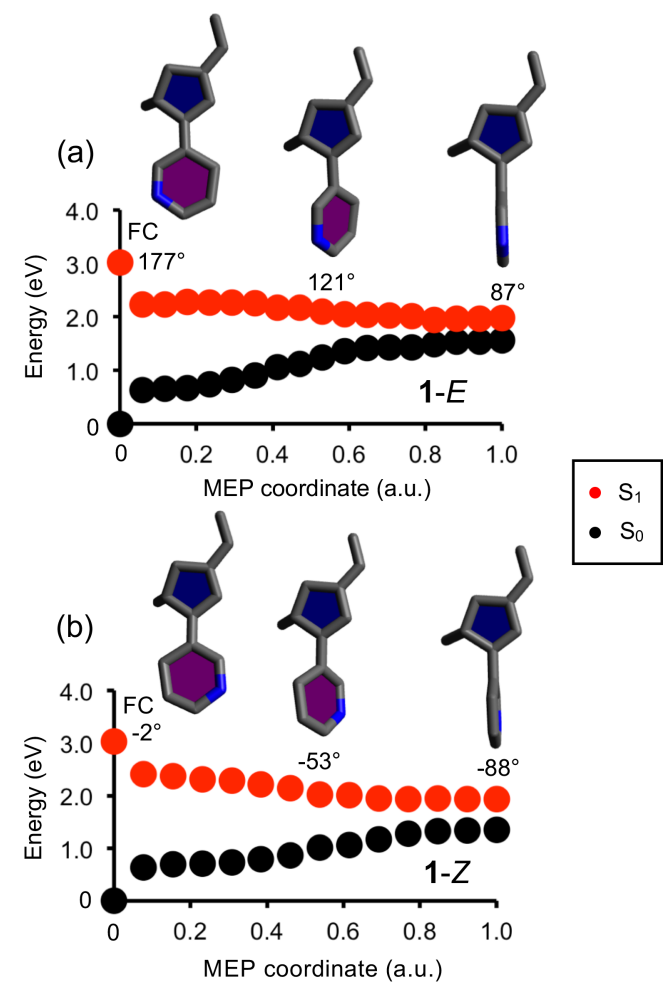

Fig. 2. MEPs from the $\mathrm{S}_{1} \mathrm{FC}$ points of the (a) $E$ and (b) $Z$ isomers of $\mathbf{1}$. Also shown are molecular snapshots along the paths and the corresponding $\omega$ dihedral angles.

While the reaction coordinates along the MEPs in Fig. 2 are dominated by torsional motion, it is also interesting to analyze what motion is not contained in the reaction coordinates. Especially, given the negative impact on the photoisomerization QYs of overcrowded-alkene motors that has been attributed to an inevitable pyramidalization of one of the central olefinic carbon atoms during the rotary motion $[16,18,42,43]$, it is pertinent to assess to what extent such 
pyramidalization occurs along the MEPs of $\mathbf{1}$. Quantifying the pyramidalization in terms of the $\alpha$ and $\alpha^{\prime}$ dihedral angles (defined in Fig. 1), this is done in Fig. 3. Notably, the pyramidalization remains small (at most $\sim 4^{\circ}$ ) for all geometries along the MEPs, which suggests that $\mathbf{1}$ may well show favorable photoisomerization dynamics.

(a)
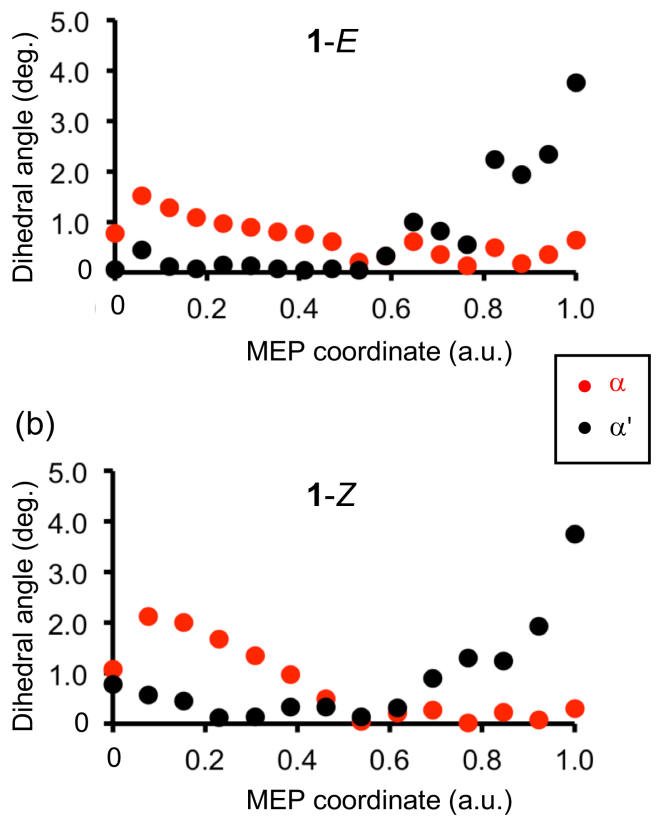

Fig. 3. $\alpha$ and $\alpha$ dihedral angles along the MEPs from the $\mathrm{S}_{1}$ FC points of the $E$ (a) and $Z$ (b) isomers of $\mathbf{1}$.

\subsection{NAMD simulations}

Three key descriptors of the photoisomerization dynamics of $\mathbf{1}$ derived from the NAMD simulations are defined in the following way. First, the rotary QY of the $E \rightarrow Z(Z \rightarrow E)$ photoisomerization is defined as the percentage of the 200 trajectories run for the $E(Z)$ isomer that form the $Z(E)$ isomer by completing a full $180^{\circ} \mathrm{CW}$ rotation around the central olefinic 
bond relative to the initial nuclear configuration within 900 fs. Second, the photoisomerization time (PIT) and the excited-state lifetime $(\tau)$ are defined as the time needed for one such rotation and the time needed for a trajectory to decay to the $S_{0}$ state, respectively. The results are summarized in Fig. 4.
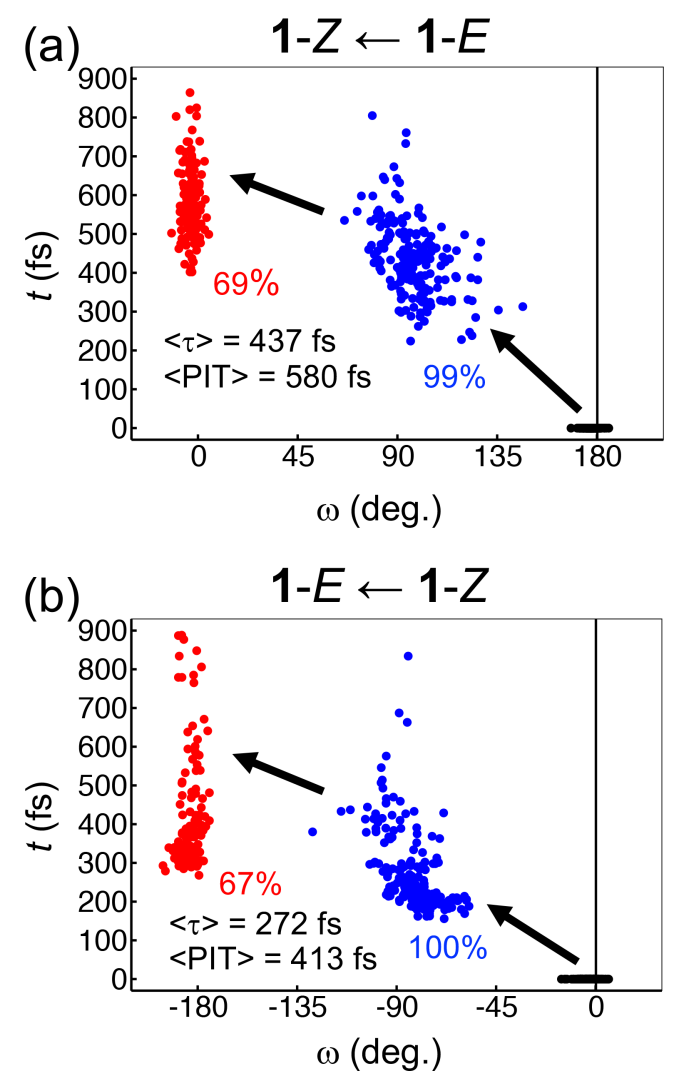

Fig. 4. Distributions of $\tau$ (blue circles) and PIT values (red circles) for the $E \rightarrow Z$ (a) and $Z \rightarrow E$ (b) NAMD trajectories of $\mathbf{1}$ and the corresponding changes in the $\omega$ dihedral angle relative to the initial nuclear configurations (black circles). Also shown are the average $\tau$ and PIT values, the percentages of trajectories that decay to the $S_{0}$ state (in blue), and the rotary QYs (in red). 
From Fig. 4, it is predicted that the photoisomerization dynamics of $\mathbf{1}$ is such that this motor would produce fast unidirectional rotary motion with high efficiency. Indeed, the average $\tau$ and PIT values are only $\sim 440$ and $\sim 580$ fs for the $E$ isomer and $\sim 270$ and $\sim 410$ fs for the $Z$ isomer, respectively. Furthermore, the rotary QY can be seen to be as high as $69 \%$ for the $E$ isomer and $67 \%$ for the $Z$ isomer. For comparison, overcrowded-alkene motors typically have excited-state lifetimes of $1 \mathrm{ps}$ or more [18,42] and photoisomerization QYs that do not exceed $20-30 \%[16,18,42,43]$. As for directionality, it is also notable that all of the 200 trajectories run for each of the two isomers start rotating in the CW direction, and that $99 \%$ of the $E \rightarrow Z$ and $100 \%$ of the $Z \rightarrow E$ trajectories decay to the $\mathrm{S}_{0}$ state. Clearly, this does not mean that 99 and $100 \%$ of the trajectories complete a full $180^{\circ} \mathrm{CW}$ rotation following the decay, because then the rotary QYs would be just as high. Rather, this means that the slightly longer time it takes for the $E$ isomer to start rotating, which is illustrated in Fig. 5 and explains why the $\tau$ and PIT values of this isomer are a little larger than those of the $Z$ isomer, has no bearing on the unidirectionality of the rotary motion. Overall, then, the NAMD simulations predict that also Schiff-base motors sufficiently large to be driven by visible light exhibit speed and efficiency that few existing molecular motors seem able to challenge. 

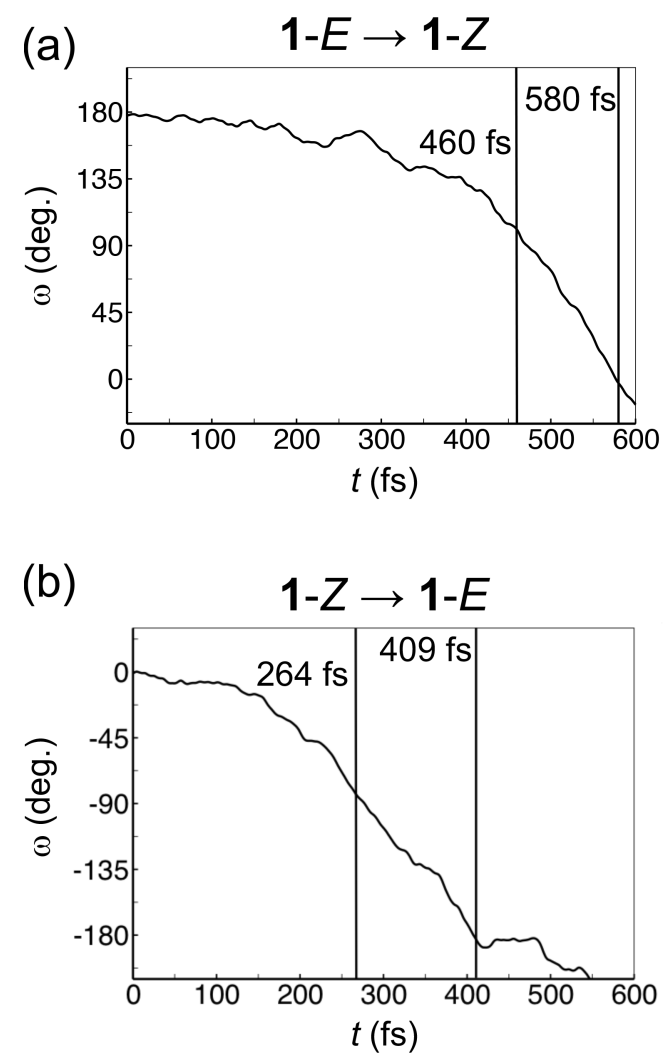

Fig. 5. Changes in the $\omega$ dihedral angle along typical NAMD trajectories of the $E$ (a) and $Z$ (b) isomers of 1 (these typical trajectories have $\tau$ and PIT values that are similar to the average $\tau$ and PIT values in Fig. 4).

Finally, as for probing the robustness of the current NAMD simulations in terms of estimated $\tau$ and PIT values, Table S3 of the Supplementary material compares these values for the five fastest (in terms of PIT) trajectories of the $Z$ isomer with the corresponding values obtained using instead Tully's fewest switches algorithm. Encouragingly, the use of Tully's method does not change the estimates of the average $\tau$ and PIT values by more than $\sim 50-60$ fs. This result, we believe, indicates that the current NAMD simulations are sufficiently accurate to enable qualitatively reliable conclusions. 


\section{Conclusions}

While UV-driven molecular motors that incorporate a protonated or alkylated nitrogen Schiff base are considered ideal motors for producing unidirectional rotary motion with high QYs, we have in this work reported quantum chemical calculations and NAMD simulations to demonstrate that Schiff-base motors can maintain this key ability also when featuring a conjugated system large enough for them to be driven by visible light. Therefore, besides being highly efficient, these synthetically feasible $[55,56]$ systems also offer a route to bypass the need to power most available light-driven molecular motors with energetic UV light, which is another key challenge in this field of research, pertaining to the long-term goal to operate the motors within biological systems and other soft materials [44]. Specifically, we have demonstrated that a Schiff-base motor (1) comprising five conjugated double bonds and responsive to photons with energies below $3 \mathrm{eV}$, is able to achieve QYs of almost $70 \%$ for its individual $E \rightarrow Z$ and $Z \rightarrow E$ photoisomerizations. Furthermore, these photoisomerizations are shown to be ultrafast, having $\tau$ values of $\sim 270-400 \mathrm{fs}$, and to produce unidirectional rotary motion without intermediary thermal steps. It is our hope that these results will stimulate continued investigation of ways to usefully exploit Schiff-base systems in the future development and application of molecular motors.

\section{Acknowledgements}

We acknowledge financial support from the Swedish Research Council (grant 621-2011-4353), the Olle Engkvist Foundation (grants 2014/734 and 184-568), the Carl Trygger Foundation (grant CTS 15:134) and Linköping University, as well as grants of computing time at the National Supercomputer Centre (NSC) in Linköping. 


\section{Appendix A. Supplementary material}

Supplementary material associated with this article can be found, in the online version, at http://dx.doi.org/xxx. 


\section{References}

[1] N. Koumura, R.W.J. Zijlstra, R.A. van Delden, N. Harada, B.L. Feringa, Light-driven monodirectional molecular rotor, Nature 401 (1999) 152-155.

[2] B.L. Feringa, The art of building small: from molecular switches to motors (Nobel lecture), Angew. Chem. Int. Ed. 56 (2017) 11060-11078.

[3] P.-T. Chiang, J. Mielke, J. Godoy, J.M. Guerrero, L.B. Alemany, C.J. Villagómez, A. Saywell, L. Grill, J.M. Tour, Toward a light-driven motorized nanocar: synthesis and initial imaging of single molecules, ACS Nano 6 (2012) 592-597.

[4] G. London, K.-Y. Chen, G.T. Carroll, B.L. Feringa, Towards dynamic control of wettability by using functionalized altitudinal molecular motors on solid surfaces, Chem. Eur. J. 19 (2013) 10690-10697.

[5] D.J. van Dijken, J. Chen, M.C.A. Stuart, L. Hou, B.L. Feringa, Amphiphilic molecular motors for responsive aggregation in water, J. Am. Chem. Soc. 138 (2016) 660-669.

[6] J. Chen, S.J. Wezenberg, B.L. Feringa, Intramolecular transport of small-molecule cargo in a nanoscale device operated by light, Chem. Commun. 52 (2016) 6765-6768.

[7] A. Saywell, A. Bakker, J. Mielke, T. Kumagai, M. Wolf, V. García-López, P.-T. Chiang, J.M. Tour, L. Grill, Light-induced translation of motorized molecules on a surface, ACS Nano 10 (2016) 10945-10952.

[8] D. Zhao, T. van Leeuwen, J. Cheng, B.L. Feringa, Dynamic control of chirality and selfassembly of double-stranded helicates with light, Nat. Chem. 9 (2017) 250-256.

[9] V. García-López, F. Chen, L.G. Nilewski, G. Duret, A. Aliyan, A.B. Kolomeisky, J.T. Robinson, G. Wang, R. Pal, J.M. Tour, Molecular machines open cell membranes, Nature 548 (2017) 567-572.

[10] N. Koumura, E.M. Geertsema, M.B. van Gelder, A. Meetsma, B.L. Feringa, Second generation light-driven molecular motors. Unidirectional rotation controlled by a single stereogenic center with near-perfect photoequilibria and acceleration of the speed of rotation by structural modification, J. Am. Chem. Soc. 124 (2002) 5037-5051.

[11] J. Vicario, M. Walko, A. Meetsma, B.L. Feringa, Fine tuning of the rotary motion by structural modification in light-driven unidirectional molecular motors, J. Am. Chem. Soc. 128 (2006) 5127-5135. 
[12] M.M. Pollard, M. Klok, D. Pijper, B.L. Feringa, Rate acceleration of light-driven rotary molecular motors, Adv. Funct. Mater. 17 (2007) 718-729.

[13] M. Klok, N. Boyle, M.T. Pryce, A. Meetsma, W.R. Browne, B.L. Feringa, MHz unidirectional rotation of molecular rotary motors, J. Am. Chem. Soc. 130 (2008) 10484 10485.

[14] M.M. Pollard, A. Meetsma, B.L. Feringa, A redesign of light-driven rotary molecular motors, Org. Biomol. Chem. 6 (2008) 507-512.

[15] A.A. Kulago, E.M. Mes, M. Klok, A. Meetsma, A.M. Brouwer, B.L. Feringa, Ultrafast light-driven nanomotors based on an acridane stator, J. Org. Chem. 75 (2010) 666-679.

[16] J. Conyard, K. Addison, I.A. Heisler, A. Cnossen, W.R. Browne, B.L. Feringa, S.R. Meech, Ultrafast dynamics in the power stroke of a molecular rotary motor, Nat. Chem. 4 (2012) 547-551.

[17] C. Fang, B. Oruganti, B. Durbeej, Computational study of the working mechanism and rate acceleration of overcrowded alkene-based light-driven rotary molecular motors, RSC Adv. 4 (2014) 10240-10251.

[18] J. Conyard, A. Cnossen, W.R. Browne, B.L. Feringa, S.R. Meech, Chemically optimizing operational efficiency of molecular rotary motors, J. Am. Chem. Soc. 136 (2014) 96929700.

[19] J. Bauer, L. Hou, J.C.M. Kistemaker, B.L. Feringa, Tuning the rotation rate of lightdriven molecular motors, J. Org. Chem. 79 (2014) 4446-4455.

[20] B. Oruganti, C. Fang, B. Durbeej, Computational design of faster rotating secondgeneration light-driven molecular motors by control of steric effects, Phys. Chem. Chem. Phys. 17 (2015) 21740-21751.

[21] B. Oruganti, J. Wang, B. Durbeej, Computational insight to improve the thermal isomerisation performance of overcrowded alkene-based molecular motors through structural redesign, ChemPhysChem 17 (2016) 3399-3408.

[22] A. Faulkner, T. van Leeuwen, B.L. Feringa, S.J. Wezenberg, Allosteric regulation of the rotational speed in a light-driven molecular motor, J. Am. Chem. Soc. 138 (2016) 1359713603.

[23] B. Oruganti, J. Wang, B. Durbeej, Quantum chemical design of rotary molecular motors, Int. J. Quantum Chem. 118 (2018) e25405. 
[24] R.A. van Delden, N. Koumura, A. Schoevaars, A. Meetsma, B.L. Feringa, A donoracceptor substituted molecular motor: unidirectional rotation driven by visible light, Org. Biomol. Chem. 1 (2003) 33-35.

[25] G. London, G.T. Carroll, T.F. Landaluce, M.M. Pollard, P. Rudolf, B.L. Feringa, Lightdriven altitudinal molecular motors on surfaces, Chem. Commun. (2009) 1712-1714.

[26] A. Cnossen, L. Hou, M.M. Pollard, P.V. Wesenhagen, W.R. Browne, B.L. Feringa, Driving unidirectional molecular rotary motors with visible light by intra- and intermolecular energy transfer from palladium porphyrin, J. Am. Chem. Soc. 134 (2012) 17613-17619.

[27] J. Vachon, G.T. Carroll, M.M. Pollard, E.M. Mes, A.M. Brouwer, B.L. Feringa, An ultrafast surface-bound photo-active molecular motor, Photochem. Photobiol. Sci. 13 (2014) 241-246.

[28] S.J. Wezenberg, K.-Y. Chen, B.L. Feringa, Visible-light-driven photoisomerization and increased rotation speed of a molecular motor acting as a ligand in a ruthenium(II) complex, Angew. Chem. Int. Ed. 54 (2015) 11457-11461.

[29] T. van Leeuwen, J. Pol, D. Roke, S.J. Wezenberg, B.L. Feringa, Visible-light excitation of a molecular motor with an extended aromatic core, Org. Lett. 19 (2017) 1402-1405.

[30] C. García-Iriepa, M. Marazzi, F. Zapata, A. Valentini, D. Sampedro, L.M. Frutos, Chiral hydrogen bond environment providing unidirectional rotation in photoactive molecular motors, J. Phys. Chem. Lett. 4 (2013) 1389-1396.

[31] L. Greb, J.-M. Lehn, Light-driven molecular motors: imines as four-step or two-step unidirectional rotors, J. Am. Chem. Soc. 136 (2014) 13114-13117.

[32] L. Greb, A. Eichhöfer, J.-M. Lehn, Synthetic molecular motors: thermal N inversion and directional photoinduced $\mathrm{C}=\mathrm{N}$ bond rotation of camphorquinone imines, Angew. Chem. Int. Ed. 54 (2015) 14345-14348.

[33] M. Guentner, M. Schildhauer, S. Thumser, P. Mayer, D. Stephenson, P.J. Mayer, H. Dube, Sunlight-powered kHz rotation of a hemithioindigo-based molecular motor, Nat. Commun. 6 (2015) 8406.

[34] G. Marchand, J. Eng, I. Schapiro, A. Valentini, L.M. Frutos, E. Pieri, M. Olivucci, J. Léonard, E. Gindensperger, Directionality of double-bond photoisomerization dynamics induced by a single stereogenic center, J. Phys. Chem. Lett. 6 (2015) 599-604. 
[35] S.C. Everhart, U.K. Jayasundara, H. Kim, R. Procúpez-Schtirbu, W.A. Stanbery, C.H. Mishler, B.J. Frost, J.I. Cline, T.W. Bell, Synthesis and photoisomerization of substituted dibenzofulvene molecular rotors, Chem. Eur. J. 22 (2016) 11291-11302.

[36] A. Nikiforov, J.A. Gamez, W. Thiel, M. Filatov, Computational design of a family of light-driven rotary molecular motors with improved quantum efficiency, J. Phys. Chem. Lett. 7 (2016) 105-110.

[37] U.K. Jayasundara, H. Kim, K.P. Sahteli, J.I. Cline, T.W. Bell, Proton-gated photoisomerization of amino-substituted dibenzofulvene rotors, ChemPhysChem 18 (2017) 59-63.

[38] J. Wang, B. Oruganti, B. Durbeej, Light-driven rotary molecular motors without point chirality: a minimal design, Phys. Chem. Chem. Phys. 19 (2017) 6952-6956.

[39] B. Oruganti, J. Wang, B. Durbeej, Excited-state aromaticity improves molecular motors: a computational analysis, Org. Lett. 19 (2017) 4818-4821.

[40] C. Petermayer, H. Dube, Indigoid photoswitches: visible light responsive molecular tools, Acc. Chem. Res. 51 (2018) 1153-1163.

[41] M. Filatov, M. Paolino, S.K. Min, K.S. Kim, Fulgides as light-driven molecular rotary motors: computational design of a prototype compound, J. Phys. Chem. Lett. 9 (2018) 4995-5001.

[42] A. Kazaryan, Z. Lan, L.V. Schäfer, W. Thiel, M. Filatov, Surface hopping excited-state dynamics study of the photoisomerization of a light-driven fluorene molecular rotary motor, J. Chem. Theory Comput. 7 (2011) 2189-2199.

[43] M. Filatov, M. Olivucci, Designing conical intersections for light-driven single molecule rotary motors: from precessional to axial motion, J. Org. Chem. 79 (2014) 3587-3600.

[44] D. Bléger, S. Hecht, Visible-light-activated molecular switches, Angew. Chem. Int. Ed. 54 (2015) 11338-11349.

[45] V. Balzani, M. Clemente-León, A. Credi, B. Ferrer, M. Venturi, A.H. Flood, J.F. Stoddart, Autonomous artificial nanomotor powered by sunlight, Proc. Natl. Acad. Sci. USA 103 (2006) 1178-1183.

[46] P. Raiteri, G. Bussi, C.S. Cucinotta, A. Credi, J.F. Stoddart, M. Parrinello, Unravelling the shuttling mechanism in a photoswitchable multicomponent bistable rotaxane, Angew. Chem. Int. Ed. 47 (2008) 3536-3539. 
[47] J. Wang, B. Durbeej, Toward fast and efficient visible-light-driven molecular motors: a minimal design, ChemistryOpen 7 (2018) 583-589.

[48] M. Assmann, C.S. Sanz, G. Pérez-Hernández, G.A. Worth, L. González, Excited state dynamics of a model asymmetric molecular rotor: a five-dimensional study on 2cyclopentylidene-tetrahydrofuran, Chem. Phys. 377 (2010) 86-95.

[49] M. Richter, P. Marquetand, J. González-Vázquez, I. Sola, L. González, SHARC: ab initio molecular dynamics with surface hopping in the adiabatic representation including arbitrary couplings, J. Chem. Theory Comput. 7 (2011) 1253-1258.

[50] M. Barbatti, Nonadiabatic dynamics with trajectory surface hopping method, WIREs Comput. Mol. Sci. 1 (2011) 620-633.

[51] B.F.E. Curchod, T.J. Martínez, Ab initio nonadiabatic quantum molecular dynamics, Chem. Rev. 118 (2018) 3305-3336.

[52] B.O. Roos, P.R. Taylor, P.E.M. Siegbahn, A complete active space SCF method (CASSCF) using a density matrix formulated super-CI approach, Chem. Phys. 48 (1980) 157-173.

[53] I.F. Galván, M.G. Delcey, T.B. Pedersen, F. Aquilante, R. Lindh, Analytical stateaverage complete-active-space self-consistent field nonadiabatic coupling vectors: implementation with density-fitted two-electron integrals and application to conical intersections, J. Chem. Theory Comput. 12 (2016) 3636-3653.

[54] F. Aquilante, J. Autschbach, R.K. Carlson, L.F. Chibotaru, M.G. Delcey, L. De Vico, I.F. Galván, N. Ferré, L.M. Frutos, L. Gagliardi, M. Garavelli, A. Giussani, C.E. Hoyer, G. Li Manni, H. Lischka, D. Ma, P.-Å. Malmqvist, T. Müller, A. Nenov, M. Olivucci, T.B. Pedersen, D. Peng, F. Plasser, B. Pritchard, M. Reiher, I. Rivalta, I. Schapiro, J. SegarraMartí, M. Stenrup, D.G. Truhlar, L. Ungur, A. Valentini, S. Vancoillie, V. Veryazov, V.P. Vysotskiy, O. Weingart, F. Zapata, R. Lindh, MOLCAS 8: new capabilities for multiconfigurational quantum chemical calculations across the periodic table, J. Comput. Chem. 37 (2016) 506-541.

[55] R.E. Gawley, S.R. Chemburkar, Generation and cyclization of nitrilium ions from amides, Heterocycles 29 (1989) 1283-1292.

[56] F. Lumento, V. Zanirato, S. Fusi, E. Busi, L. Latterini, F. Elisei, A. Sinicropi, T. Andruniów, N. Ferré, R. Basosi, M. Olivucci, Quantum chemical modeling and 
preparation of a biomimetic photochemical switch, Angew. Chem. Int. Ed. 46 (2007) 414-420.

[57] K. Andersson, P.-Å. Malmqvist, B.O. Roos, Second-order perturbation theory with a complete active space self-consistent field reference function, J. Chem. Phys. 96 (1992) $1218-1226$.

[58] O. Christiansen, H. Koch, P. Jørgensen, The second-order approximate coupled cluster singles and doubles model CC2, Chem. Phys. Lett. 243 (1995) 409-418.

[59] M. Feyereisen, G. Fitzgerald, A. Komornicki, Use of approximate integrals in ab initio theory. An application in MP2 energy calculations, Chem. Phys. Lett. 208 (1993) 359363.

[60] O. Vahtras, J. Almlöf, M.W. Feyereisen, Integral approximations for LCAO-SCF calculations, Chem. Phys. Lett. 213 (1993) 514-518.

[61] C. Hättig, F. Weigend, CC2 excitation energy calculations on large molecules using the resolution of the identity approximation, J. Chem. Phys. 113 (2000) 5154-5161.

[62] L. Du, Z. Lan, An on-the-fly surface-hopping program JADE for nonadiabatic molecular dynamics of polyatomic systems: implementation and applications, J. Chem. Theory Comput. 11 (2015) 1360-1374.

[63] J.P. Dahl, M. Springborg, The Morse oscillator in position space, momentum space, and phase space, J. Chem. Phys. 88 (1988) 4535-4547.

[64] G. Groenhof, M. Bouxin-Cademartory, B. Hess, S.P. de Visser, H.J.C. Berendsen, M. Olivucci, A.E. Mark, M.A. Robb, Photoactivation of the photoactive yellow protein: why photon absorption triggers a trans-to-cis isomerization of the chromophore in the protein, J. Am. Chem. Soc. 126 (2004) 4228-4233.

[65] L.V. Schäfer, G. Groenhof, M. Boggio-Pasqua, M.A. Robb, H. Grubmüller, Chromophore protonation state controls photoswitching of the fluoroprotein asFP595, PLoS Comput. Biol. 4 (2008) e1000034.

[66] M. Desouter-Lecomte, J.C. Lorquet, Nonadiabatic interactions in unimolecular decay. IV. Transition probability as a function of the Massey parameter, J. Chem. Phys. 71 (1979) 4391-4403.

[67] C. Wittig, The Landau-Zener formula, J. Phys. Chem. B 109 (2005) 8428-8430.

[68] J.C. Tully, Molecular dynamics with electronic transitions, J. Chem. Phys. 93 (1990) 
1061-1071.

[69] G. Granucci, M. Persico, Critical appraisal of the fewest switches algorithm for surface hopping, J. Chem. Phys. 126 (2007) 134114.

[70] M.J. Frisch, G.W. Trucks, H.B. Schlegel, G.E. Scuseria, M.A. Robb, J.R. Cheeseman, G. Scalmani, V. Barone, B. Mennucci, G.A. Petersson, H. Nakatsuji, M. Caricato, X. Li, H.P. Hratchian, A.F. Izmaylov, J. Bloino, G. Zheng, J.L. Sonnenberg, M. Hada, M. Ehara, K. Toyota, R. Fukuda, J. Hasegawa, M. Ishida, T. Nakajima, Y. Honda, O. Kitao, H. Nakai, T. Vreven, J.A. Montgomery, Jr., J.E. Peralta, F. Ogliaro, M. Bearpark, J.J. Heyd, E. Brothers, K.N. Kudin, V.N. Staroverov, R. Kobayashi, J. Normand, K. Raghavachari, A. Rendell, J.C. Burant, S.S. Iyengar, J. Tomasi, M. Cossi, N. Rega, J.M. Millam, M. Klene, J.E. Knox, J.B. Cross, V. Bakken, C. Adamo, J. Jaramillo, R. Gomperts, R.E. Stratmann, O. Yazyev, A.J. Austin, R. Cammi, C. Pomelli, J.W. Ochterski, R.L. Martin, K. Morokuma, V.G. Zakrzewski, G.A. Voth, P. Salvador, J.J. Dannenberg, S. Dapprich, A.D. Daniels, Ö. Farkas, J.B. Foresman, J.V. Ortiz, J. Cioslowski, D.J. Fox, Gaussian 09, Revision D.01, Gaussian, Inc., Wallingford, CT, USA, 2009.

[71] R. Ahlrichs, M. Bär, M. Häser, H. Horn, C. Kölmel, Electronic structure calculations on workstation computers: the program system TURBOMOLE, Chem. Phys. Lett. 162 (1989) 165-169.

[72] TURBOMOLE V6.6 2014, a development of University of Karlsruhe and Forschungszentrum Karlsruhe GmbH, 1989-2007, TURBOMOLE GmbH, since 2007, available at: http://www.turbomole.com (accessed October 28, 2018).

[73] I.B. Nielsen, L. Lammich, L.H. Andersen, $S_{1}$ and $S_{2}$ excited states of gas-phase Schiffbase retinal chromophores, Phys. Rev. Lett. 96 (2006) 018304.

[74] M. Garavelli, T. Vreven, P. Celani, F. Bernardi, M.A. Robb, M. Olivucci, Photoisomerization path for a realistic retinal chromophore model: the nonatetraeniminium cation, J. Am. Chem. Soc. 120 (1998) 1285-1288.

[75] D. Polli, P. Altoè, O. Weingart, K.M. Spillane, C. Manzoni, D. Brida, G. Tomasello, G. Orlandi, P. Kukura, R.A. Mathies, M. Garavelli, G. Cerullo, Conical intersection dynamics of the primary photoisomerization event in vision, Nature 467 (2010) 440-443. 
Molecular motors with high quantum efficiency and visible-light responsiveness: Meeting two challenges in one design

Jun Wang, Bo Durbeej*

Division of Theoretical Chemistry, IFM, Linköping University, SE-581 83 Linköping, Sweden

\section{Supplementary material}

* Corresponding author.

E-mail address: bodur@ifm.liu.se (B. Durbeej). 


\section{Contents}

Full computational details

Fig. S1

Table S1

Table S2

Table S3

Description of multimedia file

References for this document

Cartesian coordinates for $\mathrm{S}_{0}$ equilibrium geometries of $\mathbf{1}$

Cartesian coordinates for $\mathrm{S}_{1}$ MEP geometries of $\mathbf{1}$ pages S3-S5

page S6

page $\mathrm{S} 7$

page S8

page S9

page $\mathrm{S} 10$

pages S11-S13

pages S14-S21

pages S22-S51 


\section{Full computational details}

Unless otherwise noted, all calculations were done with a basis set of triple- $\zeta$ quality (cc-pVTZ).

Light-absorption calculations. The light absorption of $\mathbf{1}$ was investigated in the following way. First, the ground-state $\left(\mathrm{S}_{0}\right)$ equilibrium geometries of $1-E$ and $1-Z$ were optimized with the complete active space self-consistent field (CASSCF) method [1], second-order Møller-Plesset perturbation theory (MP2), and MP2 within the resolution-of-the-identity (RI) approximation (RIMP2) [2,3]. For comparative purposes, the RI-MP2 optimizations were carried out both with the default cc-pVTZ basis set and a double- $\zeta$ basis set (SVP). Based on the resulting geometries, the CASSCF method was then used to calculate the wave functions at the vertical Franck-Condon (FC) point in the bright and photoactive first excited singlet $\pi \pi^{*}$ state $\left(S_{1}\right)$ of $1-E$ and $1-Z$. These wave functions were subsequently employed to perform single-point calculations with the complete active space second-order perturbation theory (CASPT2) method [4] to obtain vertical $\mathrm{S}_{0} \rightarrow \mathrm{S}_{1}$ excitation energies. The corresponding oscillator strengths were calculated with the complete active space state-interaction (CASSI) method [5]. For all CASSCF and CASPT2 calculations, the active space was chosen to include the full $\pi$-system of $\mathbf{1}$, with 10 electrons distributed in 10 orbitals (i.e., CAS $(10,10))$.

As a complement to the CASPT2 results, vertical excitation energies (both $S_{0} \rightarrow S_{1}$ and $S_{0}$ $\rightarrow \mathrm{S}_{2}$ ) of 1-E and 1-Z were also calculated with the approximate coupled-cluster singles and doubles (CC2) method [6] within the RI approximation (RI-CC2) [7].

MEP calculations. The photoisomerization minimum energy paths (MEPs) of 1-E and 1- $Z$ were calculated starting from the $\mathrm{S}_{1}$ FC points (at the CASSCF/cc-pVTZ $\mathrm{S}_{0}$ equilibrium geometries) 
using a state-averaged CASSCF (SA-CASSCF) approach with equal weights (0.5) for $\mathrm{S}_{0}$ and $\mathrm{S}_{1}$. These calculations were done with the same active space as the light-absorption calculations, i.e., with CAS $(10,10)$. The $S_{0}$ and $S_{1}$ energies of the resulting $S_{1}$ MEP geometries were subsequently refined by performing CASPT2 single-point calculations to include dynamic electron correlation effects.

NAMD simulations. The non-adiabatic molecular dynamics (NAMD) simulations of the photoisomerizations of 1 were carried out using SA-CASSCF $(10,10)$, with equal weights for $\mathrm{S}_{0}$ and $S_{1}$, in combination with the SVP basis set. First, following calculation of the $S_{0}$ vibrational normal modes of $1-E$ and $1-Z$ at the RI-MP2/SVP level of theory, 200 different initial nuclear configurations and velocities for each of the two isomers were generated from a harmonicoscillator Wigner distribution [8,9] using the JADE program [10]. These initial conditions were then used to start 200 photoisomerization trajectories from the $S_{1} \mathrm{FC}$ point of the respective isomer. Evaluating nuclear forces "on the fly", the trajectories were propagated classically for a maximum of 900 fs employing the velocity Verlet algorithm [11] with a fixed integration time step of 1 fs.

Using the algorithm by Robb and co-workers $[12,13]$ as implemented in the MOLCAS 8.0 suite of programs [14], the non-adiabatic coupling $\left\langle\Psi_{1} \mid \frac{\partial}{\partial \mathbf{R}} \Psi_{0}\right\rangle$ between the $S_{1}$ and $S_{0}$ states during the simulations was evaluated in the framework of Landau-Zener theory $[15,16]$. In this algorithm/framework, the accuracy of which was tested through a comparison with Tully's fewest switches algorithm (see further below) [17], the coupling is large when $\left\langle\Psi_{1} \mid \frac{\partial}{\partial t} \Psi_{0}\right\rangle$ is large, as calculated using the numerical approximation $\left\langle\Psi_{1}(t) \mid \frac{\partial}{\partial t} \Psi_{0}(t)\right\rangle \approx\left\langle\Psi_{1}(t) \mid \Psi_{0}(t+\Delta t)\right\rangle / \Delta t$. Performing this calculation at each trajectory step for which the energy gap between the two states 
is smaller than 0.03 a.u., a trajectory was allowed to hop from the $S_{1}$ state to the $S_{0}$ state (but not from $S_{0}$ back to $\left.S_{1}\right)$ subject to the condition that $\left\langle\Psi_{1}(t) \mid \Psi_{0}(t+\Delta t)\right\rangle$ exceeds a default value $(0.25)$ signaling - by virtue of the associated deviation of the $S_{1}$ and $S_{0}$ wave functions from orthogonality - the proximity of a $S_{1} / S_{0}$ conical intersection decay channel. The procedure to allow only a single hop between the two states (from $S_{1}$ to $S_{0}$ ) has been validated quantitatively in a previous NAMDsimulation study of Schiff-base motors, albeit that that study focused on smaller motors featuring only three conjugated double bonds [18]. Specifically, it was shown that allowing up to five hops back and forth between the $S_{1}$ and $S_{0}$ states does not affect the predictions of key quantities like photoisomerization times and quantum yields by more than $10 \%$ [18].

Finally, for comparative purposes, NAMD simulations were also carried out using Tully's fewest switches algorithm, which couples the classical propagation of the nuclear motion with the electronic motion as described by the time-dependent Schrödinger equation (TSDE) [17]. These simulations were run with the five sets of initial conditions that, when used for the simulations based on Robb's algorithm described above, yielded the five fastest trajectories for 1- $Z$ in terms of photoisomerization time (see main text for how this quantity is defined). Again, Newton's equations of motion for the nuclei were integrated with a time step of $1 \mathrm{fs}$, whereas the TDSE was integrated with a time step of 5 as. Following the suggestion by Granucci and Persico, a decoherence correction of 0.1 a.u. was used in these simulations [19].

Software used. The MP2 calculations were done with Gaussian 09 [20]. The RI-MP2 and RI-CC2 calculations were done with TURBOMOLE $6.6[21,22]$. All other calculations were done with MOLCAS 8.0 or OpenMolcas 18.09 (NAMD simulations with Tully's fewest switches algorithm) [14]. 


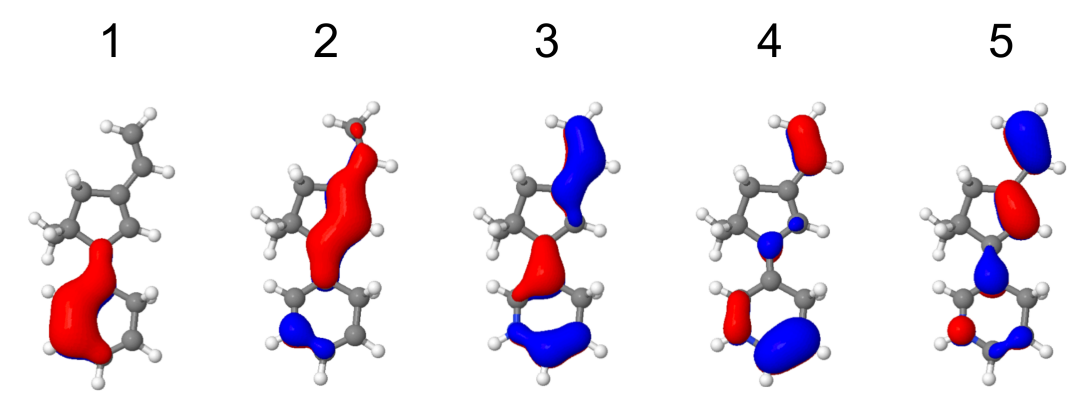

\section{$1-E$}
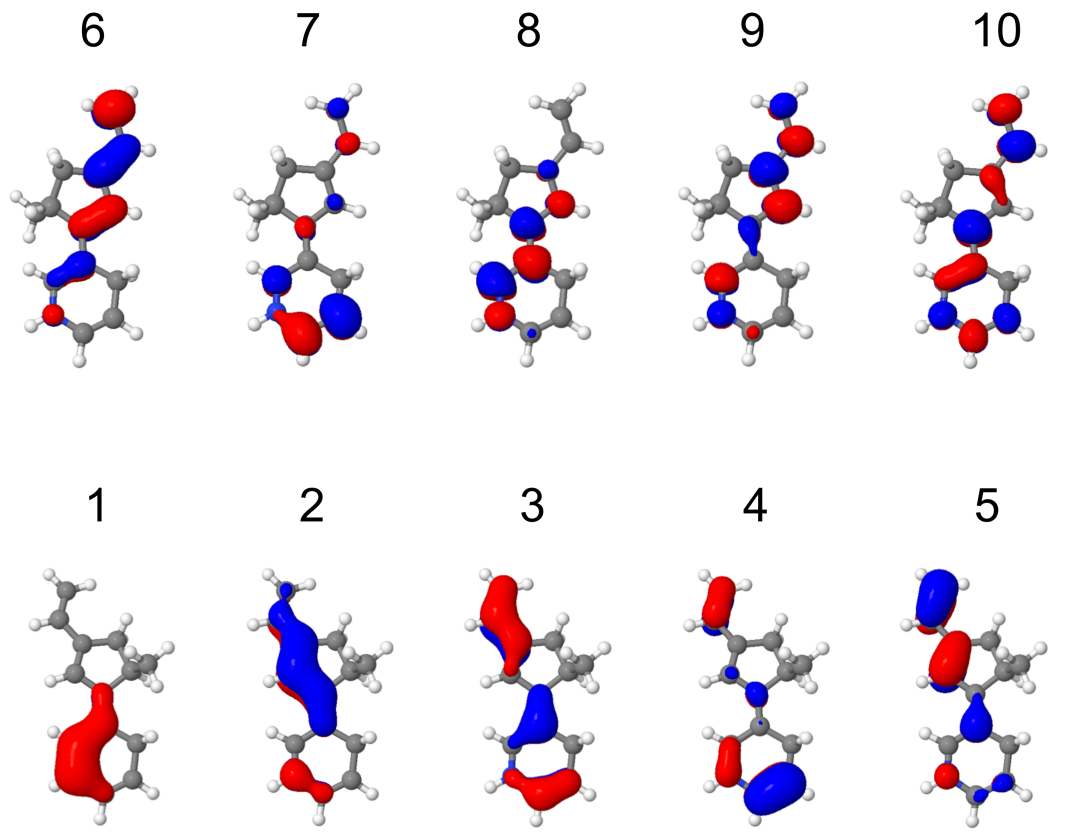

\section{$1-Z$}

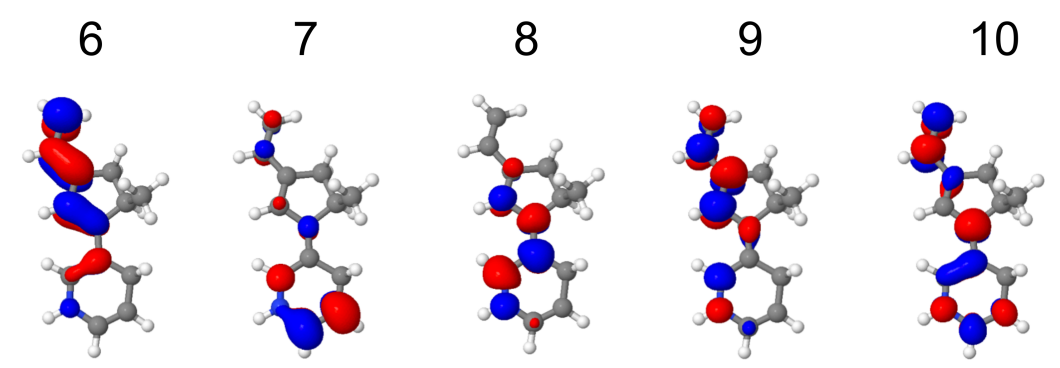

Fig. S1. Active CASSCF molecular orbitals 1-10 at the CASSCF $\mathrm{S}_{0}$ equilibrium geometries of the $E$ and $Z$ isomers of $\mathbf{1}$. 
Table S1

CASSCF occupation numbers for active molecular orbitals 1-10 in the $\mathrm{S}_{0}$ and $\mathrm{S}_{1}$ states of the $E$ and $Z$ isomers of $\mathbf{1}^{\text {a }}$

\begin{tabular}{llcccccccccc}
\hline \multicolumn{10}{c}{} & \multicolumn{10}{c}{ Active molecular orbital } \\
\hline Isomer & State & 1 & 2 & 3 & 4 & 5 & 6 & 7 & 8 & 9 & 10 \\
\hline$E$ & $\mathrm{~S}_{0}$ & 1.97 & 1.95 & 1.93 & 1.91 & 1.88 & 0.13 & 0.09 & 0.05 & 0.03 & 0.07 \\
& $\mathrm{~S}_{1}$ & 1.97 & 1.94 & 1.91 & 1.90 & 1.33 & 0.68 & 0.11 & 0.06 & 0.04 & 0.07 \\
$Z$ & $\mathrm{~S}_{0}$ & 1.97 & 1.95 & 1.93 & 1.91 & 1.88 & 0.13 & 0.09 & 0.03 & 0.05 & 0.07 \\
& $\mathrm{~S}_{1}$ & 1.97 & 1.94 & 1.92 & 1.90 & 1.10 & 0.90 & 0.11 & 0.03 & 0.06 & 0.07 \\
\hline
\end{tabular}

${ }^{a}$ All calculations carried out with the cc-pVTZ basis set and CASSCF/cc-pVTZ $\mathrm{S}_{0}$ equilibrium geometries. 
Table S2

Vertical RI-CC2 excitation energies of the $E$ and $Z$ isomers of $\mathbf{1}$ (in $\mathrm{eV}$ ). ${ }^{\text {a }}$

\begin{tabular}{llcc}
\hline $\mathrm{S}_{0}$ equilibrium geometry & Excitation & $E$ isomer & $Z$ isomer \\
\hline CASSCF/cc-pVTZ & $\mathrm{S}_{0} \rightarrow \mathrm{S}_{1}$ & $2.99(0.76)$ & $2.99(0.67)$ \\
CASSCF/cc-pVTZ & $\mathrm{S}_{0} \rightarrow \mathrm{S}_{2}$ & $4.32(0.19)$ & $4.42(0.03)$ \\
MP2/cc-pVTZ & $\mathrm{S}_{0} \rightarrow \mathrm{S}_{1}$ & $2.82(0.73)$ & $2.86(0.71)$ \\
MP2/cc-pVTZ & $\mathrm{S}_{0} \rightarrow \mathrm{S}_{2}$ & $4.20(0.25)$ & $4.28(0.06)$ \\
RI-MP2/cc-pVTZ & $\mathrm{S}_{0} \rightarrow \mathrm{S}_{1}$ & $2.84(0.73)$ & $2.88(0.71)$ \\
RI-MP2/cc-pVTZ & $\mathrm{S}_{0} \rightarrow \mathrm{S}_{2}$ & $4.23(0.26)$ & $4.32(0.06)$ \\
RI-MP2/SVP & $\mathrm{S}_{0} \rightarrow \mathrm{S}_{1}$ & $2.78(0.73)$ & $2.82(0.70)$ \\
RI-MP2/SVP & $\mathrm{S}_{0} \rightarrow \mathrm{S}_{2}$ & $4.15(0.25)$ & $4.24(0.06)$ \\
\hline
\end{tabular}

${ }^{a}$ All calculations carried out with the cc-pVTZ basis set. Oscillator strengths in parentheses. 


\section{Table S3}

Comparison of $\tau$ and PIT values (in fs) for five NAMD trajectories run for the $Z$ isomer of 1 with different algorithms.

\begin{tabular}{lcccc}
\hline & \multicolumn{2}{c}{ Landau-Zener algorithm $^{\mathrm{a}}$} & \multicolumn{2}{c}{ Tully's fewest switches algorithm $^{\mathrm{b}}$} \\
\hline Trajectory & $\tau$ & PIT & $\tau$ & PIT \\
\hline 1 & 189 & 268 & 385 & 435 \\
2 & 195 & 285 & 318 & 358 \\
3 & 163 & 289 & 161 & 268 \\
4 & 200 & 291 & 200 & 291 \\
5 & 192 & 292 & 184 & 296 \\
average $^{c}$ & 188 & 285 & 250 & 330 \\
\hline
\end{tabular}

a Algorithm described in Refs. [12-14].

${ }^{\mathrm{b}}$ Algorithm described in Refs. [14,17].

${ }^{\mathrm{c}}$ Average value over all trajectories. 


\section{Description of multimedia file}

The file e-z-e.avi contains a movie from the NAMD simulations of $\mathbf{1}$ showing two representative

trajectories (one for 1- $E$ and one for 1-Z) merged together to illustrate a full $360^{\circ} E \rightarrow Z \rightarrow E$ rotation around the central olefinic bond. 


\section{References for this document}

[1] B.O. Roos, P.R. Taylor, P.E.M. Siegbahn, A complete active space SCF method (CASSCF) using a density matrix formulated super-CI approach, Chem. Phys. 48 (1980) $157-173$.

[2] M. Feyereisen, G. Fitzgerald, A. Komornicki, Use of approximate integrals in ab initio theory. An application in MP2 energy calculations, Chem. Phys. Lett. 208 (1993) 359-363.

[3] O. Vahtras, J. Almlöf, M.W. Feyereisen, Integral approximations for LCAO-SCF calculations, Chem. Phys. Lett. 213 (1993) 514-518.

[4] K. Andersson, P.-A. Malmqvist, B.O. Roos, Second-order perturbation theory with a complete active space self-consistent field reference function, J. Chem. Phys. 96 (1992) 1218-1226.

[5] P.- Å. Malmqvist, B.O. Roos, The CASSCF state interaction method, Chem. Phys. Lett. 155 (1989) 189-194.

[6] O. Christiansen, H. Koch, P. Jørgensen, The second-order approximate coupled cluster singles and doubles model CC2, Chem. Phys. Lett. 243 (1995) 409-418.

[7] C. Hättig, F. Weigend, CC2 excitation energy calculations on large molecules using the resolution of the identity approximation, J. Chem. Phys. 113 (2000) 5154-5161.

[8] J.P. Dahl, M. Springborg, The Morse oscillator in position space, momentum space, and phase space, J. Chem. Phys. 88 (1988) 4535-4547.

[9] R. Schinke, Photodissociation Dynamics: Spectroscopy and Fragmentation of Small Polyatomic Molecules, Cambridge University Press, Cambridge, U.K., 1993.

[10] L. Du, Z. Lan, An on-the-fly surface-hopping program JADE for nonadiabatic molecular dynamics of polyatomic systems: implementation and applications, J. Chem. Theory Comput. 11 (2015) 1360-1374.

[11] L. Verlet, Computer "experiments" on classical fluids. I. Thermodynamical properties of Lennard-Jones molecules, Phys. Rev. 159 (1967) 98-103.

[12] G. Groenhof, M. Bouxin-Cademartory, B. Hess, S.P. de Visser, H.J.C. Berendsen, M. Olivucci, A.E. Mark, M.A. Robb, Photoactivation of the photoactive yellow protein: why photon absorption triggers a trans-to-cis isomerization of the chromophore in the protein, J. Am. Chem. Soc. 126 (2004) 4228-4233. 
[13] L.V. Schäfer, G. Groenhof, M. Boggio-Pasqua, M.A. Robb, H. Grubmüller, Chromophore protonation state controls photoswitching of the fluoroprotein asFP595, PLoS Comput. Biol. 4 (2008) e1000034.

[14] F. Aquilante, J. Autschbach, R.K. Carlson, L.F. Chibotaru, M.G. Delcey, L. De Vico, I.F. Galván, N. Ferré, L.M. Frutos, L. Gagliardi, M. Garavelli, A. Giussani, C.E. Hoyer, G. Li Manni, H. Lischka, D. Ma, P.-Å. Malmqvist, T. Müller, A. Nenov, M. Olivucci, T.B. Pedersen, D. Peng, F. Plasser, B. Pritchard, M. Reiher, I. Rivalta, I. Schapiro, J. SegarraMartí, M. Stenrup, D.G. Truhlar, L. Ungur, A. Valentini, S. Vancoillie, V. Veryazov, V.P. Vysotskiy, O. Weingart, F. Zapata, R. Lindh, MOLCAS 8: new capabilities for multiconfigurational quantum chemical calculations across the periodic table, J. Comput. Chem. 37 (2016) 506-541.

[15] M. Desouter-Lecomte, J.C. Lorquet, Nonadiabatic interactions in unimolecular decay. IV. Transition probability as a function of the Massey parameter, J. Chem. Phys. 71 (1979) 4391-4403.

[16] C. Wittig, The Landau-Zener formula, J. Phys. Chem. B 109 (2005) 8428-8430.

[17] J.C. Tully, Molecular dynamics with electronic transitions, J. Chem. Phys. 93 (1990) 10611071.

[18] J. Wang, B. Oruganti, B. Durbeej, Light-driven rotary molecular motors without point chirality: a minimal design, Phys. Chem. Chem. Phys. 19 (2017) 6952-6956.

[19] G. Granucci, M. Persico, Critical appraisal of the fewest switches algorithm for surface hopping, J. Chem. Phys. 126 (2007) 134114.

[20] M.J. Frisch, G.W. Trucks, H.B. Schlegel, G.E. Scuseria, M.A. Robb, J.R. Cheeseman, G. Scalmani, V. Barone, B. Mennucci, G.A. Petersson, H. Nakatsuji, M. Caricato, X. Li, H.P. Hratchian, A.F. Izmaylov, J. Bloino, G. Zheng, J.L. Sonnenberg, M. Hada, M. Ehara, K. Toyota, R. Fukuda, J. Hasegawa, M. Ishida, T. Nakajima, Y. Honda, O. Kitao, H. Nakai, T. Vreven, J.A. Montgomery, Jr., J.E. Peralta, F. Ogliaro, M. Bearpark, J.J. Heyd, E. Brothers, K.N. Kudin, V.N. Staroverov, R. Kobayashi, J. Normand, K. Raghavachari, A. Rendell, J.C. Burant, S.S. Iyengar, J. Tomasi, M. Cossi, N. Rega, J.M. Millam, M. Klene, J.E. Knox, J.B. Cross, V. Bakken, C. Adamo, J. Jaramillo, R. Gomperts, R.E. Stratmann, O. Yazyev, A.J. Austin, R. Cammi, C. Pomelli, J.W. Ochterski, R.L. Martin, K. Morokuma, V.G. Zakrzewski, G.A. Voth, P. Salvador, J.J. Dannenberg, S. Dapprich, A.D. 
Daniels, Ö. Farkas, J.B. Foresman, J.V. Ortiz, J. Cioslowski, D.J. Fox, Gaussian 09, Revision D.01, Gaussian, Inc., Wallingford, CT, USA, 2009.

[21] R. Ahlrichs, M. Bär, M. Häser, H. Horn, C. Kölmel, Electronic structure calculations on workstation computers: the program system TURBOMOLE, Chem. Phys. Lett. 162 (1989) 165-169.

[22] TURBOMOLE V6.6 2014, a development of University of Karlsruhe and Forschungszentrum Karlsruhe GmbH, 1989-2007, TURBOMOLE GmbH, since 2007, available at: http://www.turbomole.com (accessed October 28, 2018). 


\section{Cartesian coordinates for $S_{0}$ equilibrium geometries of 1 (in $\AA$ )}

$\begin{array}{lrrr}\text { 1-E, CASSCF/cc-pVTZ } & \\ \text { C } & 2.12354033 & 0.92347615 & -0.35007579 \\ \mathrm{C} & 1.24817031 & -0.14906846 & -0.03252274 \\ \mathrm{C} & 1.85080802 & -1.51839955 & 0.24851049 \\ \mathrm{C} & -0.09963696 & 0.07448536 & -0.01728192 \\ \mathrm{C} & -1.09603567 & -0.94357015 & 0.21801020 \\ \mathrm{C} & -0.83163704 & 1.39423392 & -0.23840501 \\ \mathrm{C} & -2.34200460 & -0.47703488 & -0.02598586 \\ \mathrm{H} & -0.45123662 & 1.90803618 & -1.11185964 \\ \mathrm{C} & -2.29527334 & 0.96007404 & -0.47462627 \\ \mathrm{H} & -2.56671298 & 1.03057853 & -1.52149342 \\ \mathrm{H} & -2.99025754 & 1.57967067 & 0.07595351 \\ \mathrm{H} & -0.87297087 & -1.94884446 & 0.51138452 \\ \mathrm{H} & 1.47305931 & -2.24636458 & -0.46057788 \\ \mathrm{H} & 1.54695261 & -1.86476671 & 1.22943850 \\ \mathrm{~N} & 3.40850751 & 0.78753827 & -0.39043784 \\ \mathrm{C} & -3.56070456 & -1.26513611 & 0.08488505 \\ \mathrm{H} & -3.44102850 & -2.27927830 & 0.41997793 \\ \mathrm{C} & -4.78799317 & -0.81012451 & -0.20462306 \\ \mathrm{H} & -4.96445640 & 0.19133053 & -0.54683071 \\ \mathrm{H} & -5.64700988 & -1.44337499 & -0.10397090 \\ \mathrm{C} & 4.06991746 & -0.44318705 & -0.11371142 \\ \mathrm{H} & 5.13565454 & -0.40168521 & -0.17126525 \\ \mathrm{C} & 3.35299225 & -1.52032636 & 0.18451686 \\ \mathrm{H} & 3.86679694 & -2.43852351 & 0.38761156 \\ \mathrm{H} & 3.96826656 & 1.57643934 & -0.63002110 \\ \mathrm{C} & -0.71730117 & 2.31914490 & 0.98047524 \\ \mathrm{H} & -1.11286476 & 1.83768766 & 1.86663128 \\ \mathrm{H} & 0.30724261 & 2.60190046 & 1.19004327 \\ \mathrm{H} & -1.28223374 & 3.22621258 & 0.81033823 \\ \mathrm{H} & 1.74436535 & 1.89730025 & -0.58086181 \\ & & & \\ & & & \\ & & \\ & & \\ & & \end{array}$




\section{1-Z, CASSCF/cc-pVTZ}

$\begin{array}{rrrr}\mathrm{C} & 1.82662348 & -1.33927511 & 0.25574204 \\ \mathrm{C} & 1.26596382 & -0.05794287 & -0.00691705 \\ \mathrm{C} & 2.21149090 & 1.08067429 & -0.36348309 \\ \mathrm{C} & -0.09377206 & 0.08544955 & 0.03337936 \\ \mathrm{C} & -1.09691267 & -0.93407120 & 0.27858082 \\ \mathrm{C} & -0.83235381 & 1.38823489 & -0.22113196 \\ \mathrm{C} & -2.33424539 & -0.48083942 & -0.01956172 \\ \mathrm{H} & -0.40307748 & 1.90808729 & -1.06767375 \\ \mathrm{C} & -2.27813209 & 0.94018014 & -0.51771188 \\ \mathrm{H} & -2.49522061 & 0.96814275 & -1.57935924 \\ \mathrm{H} & -3.00446897 & 1.57342956 & -0.02714407 \\ \mathrm{H} & -0.90086607 & -1.93133766 & 0.61652951 \\ \mathrm{H} & 2.13107213 & 1.88312421 & 0.35810342 \\ \mathrm{H} & 1.93435384 & 1.50847155 & -1.31982964 \\ \mathrm{~N} & 3.09479983 & -1.57602545 & 0.19018458 \\ \mathrm{C} & -3.55287849 & -1.27283442 & 0.07897987 \\ \mathrm{H} & -3.44025528 & -2.27430006 & 0.45313518 \\ \mathrm{C} & -4.77220695 & -0.83619890 & -0.26549041 \\ \mathrm{H} & -4.94249354 & 0.15168693 & -0.64773341 \\ \mathrm{H} & -5.63065652 & -1.47115400 & -0.17065209 \\ \mathrm{C} & 4.05496680 & -0.58565760 & -0.16467155 \\ \mathrm{H} & 5.06537516 & -0.93063228 & -0.19378830 \\ \mathrm{C} & 3.65081130 & 0.65069355 & -0.42950719 \\ \mathrm{H} & 4.38467021 & 1.38482887 & -0.69568033 \\ \mathrm{H} & 3.42216745 & -2.49708230 & 0.38477042 \\ \mathrm{C} & -0.78066482 & 2.30734110 & 1.00826007 \\ \mathrm{H} & -1.24210728 & 1.82840803 & 1.86355811 \\ \mathrm{H} & 0.22967751 & 2.57804784 & 1.28167564 \\ \mathrm{H} & -1.32226798 & 3.22105473 & 0.80237170 \\ \mathrm{H} & 1.20765259 & -2.17088602 & 0.52000996\end{array}$




$\begin{array}{lrrr}\text { 1-E, MP2/cc-pVTZ } & & \\ \mathrm{C} & & & \\ \mathrm{C} & 2.09972100 & 0.93430200 & -0.33592700 \\ \mathrm{C} & 1.25613300 & -0.14397000 & -0.04887500 \\ \mathrm{C} & 1.84616000 & -1.51009400 & 0.23964300 \\ \mathrm{C} & -0.11283700 & 0.06382600 & -0.05909300 \\ \mathrm{C} & -1.07459700 & -0.95572100 & 0.16258600 \\ \mathrm{C} & -0.83434000 & 1.37707400 & -0.25470800 \\ \mathrm{H} & -2.34391100 & -0.48068200 & -0.05886600 \\ \mathrm{C} & -0.43987200 & 1.93335600 & -1.10524300 \\ \mathrm{H} & -2.29475400 & 0.95084700 & -0.50070400 \\ \mathrm{H} & -2.55562500 & 1.01297800 & -1.55990200 \\ \mathrm{H} & -3.00407200 & 1.57444900 & 0.04434200 \\ \mathrm{H} & -0.84811100 & -1.97438100 & 0.44286900 \\ \mathrm{H} & 1.46786900 & -2.24270200 & -0.47937100 \\ \mathrm{~N} & 1.51783200 & -1.85902300 & 1.22273200 \\ \mathrm{C} & 3.41386100 & 0.81437600 & -0.35617100 \\ \mathrm{H} & -3.54433300 & -1.25919500 & 0.07679100 \\ \mathrm{C} & -3.43769200 & -2.28614100 & 0.40318300 \\ \mathrm{H} & -4.76908200 & -0.76495800 & -0.18524200 \\ \mathrm{H} & -4.90810600 & 0.25451200 & -0.51740100 \\ \mathrm{C} & -5.65185900 & -1.37700900 & -0.07329900 \\ \mathrm{H} & 4.06074300 & -0.40812200 & -0.08392000 \\ \mathrm{C} & 5.13711300 & -0.37960500 & -0.12215000 \\ \mathrm{H} & 3.34576200 & -1.50035300 & 0.19494100 \\ \mathrm{H} & 3.87631600 & -2.41950800 & 0.39560400 \\ \mathrm{C} & 3.97662900 & 1.62191500 & -0.58007900 \\ \mathrm{H} & -0.73279000 & 2.23084400 & 1.01624800 \\ \mathrm{H} & -1.16185400 & 1.69154500 & 1.86097800 \\ \mathrm{H} & 0.30099100 & 2.47042000 & 1.26111500 \\ \mathrm{H} & -1.28111600 & 3.16238100 & 0.88768600 \\ & 1.70327800 & 1.91338900 & -0.56511100\end{array}$




$\begin{array}{lrrr}\mathrm{C} & 1.83255600 & -1.34569900 & 0.20491000 \\ \mathrm{C} & 1.26598000 & -0.09348500 & -0.06067200 \\ \mathrm{C} & 2.16407200 & 1.07020800 & -0.43219100 \\ \mathrm{C} & -0.11546200 & 0.03411200 & -0.02304800 \\ \mathrm{C} & -1.09812200 & -0.97008100 & 0.21129900 \\ \mathrm{C} & -0.82219900 & 1.34459600 & -0.22751600 \\ \mathrm{C} & -2.35182800 & -0.48209300 & -0.04776000 \\ \mathrm{H} & -0.37337500 & 1.91728400 & -1.04020600 \\ \mathrm{C} & -2.27560500 & 0.93931000 & -0.52231300 \\ \mathrm{H} & -2.49123700 & 0.97644900 & -1.59281600 \\ \mathrm{H} & -2.99779000 & 1.58396800 & -0.02161900 \\ \mathrm{H} & -0.91247200 & -1.98905100 & 0.51915700 \\ \mathrm{H} & 1.96406700 & 1.93114200 & 0.20810500 \\ \mathrm{H} & 1.93915300 & 1.40372900 & -1.45023200 \\ \mathrm{~N} & 3.13524000 & -1.54728700 & 0.19949800 \\ \mathrm{C} & -3.56715600 & -1.24368100 & 0.07298500 \\ \mathrm{H} & -3.48260900 & -2.26378400 & 0.42684600 \\ \mathrm{C} & -4.77772400 & -0.74367800 & -0.23478500 \\ \mathrm{H} & -4.89624800 & 0.26843800 & -0.59591600 \\ \mathrm{H} & -5.66983300 & -1.34362600 & -0.13252700 \\ \mathrm{C} & 4.05642000 & -0.50984700 & -0.05305900 \\ \mathrm{H} & 5.09523800 & -0.78811700 & 0.01122100 \\ \mathrm{C} & 3.61943600 & 0.71783200 & -0.34065600 \\ \mathrm{H} & 4.35154200 & 1.49083500 & -0.52255900 \\ \mathrm{H} & 3.48866200 & -2.47092900 & 0.40300900 \\ \mathrm{C} & -0.75334500 & 2.15715800 & 1.07742300 \\ \mathrm{H} & -1.27469200 & 1.61751600 & 1.86808900 \\ \mathrm{H} & 0.26937500 & 2.33262700 & 1.40488700 \\ \mathrm{H} & -1.23715500 & 3.12189900 & 0.93754900 \\ \mathrm{H} & 1.21856200 & -2.20528400 & 0.43282000\end{array}$




$\begin{array}{lrrr}\text { 1- } E, \text { RI-MP } 2 / \mathrm{cc}-\mathrm{pVTZ} & \\ \mathrm{C} & 2.0927299 & 0.9319034 & -0.3434427 \\ \mathrm{C} & 1.2505218 & -0.1378374 & -0.0543657 \\ \mathrm{C} & 1.8336925 & -1.4978735 & 0.2339137 \\ \mathrm{C} & -0.1102772 & 0.0691137 & -0.0593338 \\ \mathrm{C} & -1.0669328 & -0.9439310 & 0.1700721 \\ \mathrm{C} & -0.8296661 & 1.3733147 & -0.2555407 \\ \mathrm{C} & -2.3307553 & -0.4744551 & -0.0536510 \\ \mathrm{H} & -0.4342051 & 1.9373415 & -1.0955392 \\ \mathrm{C} & -2.2821496 & 0.9459287 & -0.5072803 \\ \mathrm{H} & -2.5336447 & 0.9949461 & -1.5658017 \\ \mathrm{H} & -2.9936803 & 1.5720984 & 0.0244810 \\ \mathrm{H} & -0.8417881 & -1.9558306 & 0.4572841 \\ \mathrm{H} & 1.4592268 & -2.2268258 & -0.4855958 \\ \mathrm{H} & 1.5010779 & -1.8479918 & 1.2111483 \\ \mathrm{~N} & 3.4018443 & 0.8106400 & -0.3636897 \\ \mathrm{C} & -3.5254386 & -1.2469019 & 0.0840287 \\ \mathrm{H} & -3.4199182 & -2.2667770 & 0.4171816 \\ \mathrm{C} & -4.7460438 & -0.7592279 & -0.1836261 \\ \mathrm{H} & -4.8846407 & 0.2536147 & -0.5234421 \\ \mathrm{H} & -5.6247087 & -1.3698336 & -0.0690915 \\ \mathrm{C} & 4.0426401 & -0.4075068 & -0.0844186 \\ \mathrm{H} & 5.1147854 & -0.3831901 & -0.1181198 \\ \mathrm{C} & 3.3264248 & -1.4919378 & 0.1970862 \\ \mathrm{H} & 3.8491547 & -2.4079099 & 0.4049970 \\ \mathrm{H} & 3.9652895 & 1.6145458 & -0.5902900 \\ \mathrm{C} & -0.7382303 & 2.2097613 & 1.0205237 \\ \mathrm{H} & -1.1702441 & 1.6575989 & 1.8510204 \\ \mathrm{H} & 0.2904080 & 2.4462635 & 1.2752847 \\ \mathrm{H} & -1.2869717 & 3.1385130 & 0.9029414 \\ \mathrm{H} & 1.6989581 & 1.9071957 & -0.5740783\end{array}$




$\begin{array}{lrrr}\text { 1-Z, RI-MP2/cc-pVTZ } & \\ \text { C } & 1.8215052 & -1.3295501 & 0.2220037 \\ \text { C } & 1.2607892 & -0.0849009 & -0.0537677 \\ \text { C } & 2.1571391 & 1.0694696 & -0.4262361 \\ \text { C } & -0.1124356 & 0.0443723 & -0.0186908 \\ \text { C } & -1.0897293 & -0.9505856 & 0.2341017 \\ \text { C } & -0.8160117 & 1.3432452 & -0.2441964 \\ \text { C } & -2.3381209 & -0.4714862 & -0.0319416 \\ \text { H } & -0.3682335 & 1.9047801 & -1.0601681 \\ \text { C } & -2.2634113 & 0.9343944 & -0.5301785 \\ \text { H } & -2.4803509 & 0.9520487 & -1.5971627 \\ \text { H } & -2.9819046 & 1.5855687 & -0.0406845 \\ \text { H } & -0.9036052 & -1.9594075 & 0.5589119 \\ \text { H } & 1.9883629 & 1.9158350 & 0.2368069 \\ \text { H } & 1.9069834 & 1.4294790 & -1.4252169 \\ \text { N } & 3.1173552 & -1.5412129 & 0.2023804 \\ \text { C } & -3.5472972 & -1.2268574 & 0.0967988 \\ \text { H } & -3.4641594 & -2.2352685 & 0.4694485 \\ \text { C } & -4.7534869 & -0.7397305 & -0.2262670 \\ \text { H } & -4.8724063 & 0.2605784 & -0.6077659 \\ \text { H } & -5.6407981 & -1.3386884 & -0.1173707 \\ \text { C } & 4.0366112 & -0.5208922 & -0.0941130 \\ \text { H } & 5.0704547 & -0.8059937 & -0.0618036 \\ \text { C } & 3.6037990 & 0.7014376 & -0.3869276 \\ \text { H } & 4.3325807 & 1.4601474 & -0.6085249 \\ \text { H } & 3.4658859 & -2.4629921 & 0.4126900 \\ \text { C } & -0.7503897 & 2.1675552 & 1.0461521 \\ \text { H } & -1.2704161 & 1.6344052 & 1.8374463 \\ \text { H } & 0.2679647 & 2.3480758 & 1.3729257 \\ \text { H } & -1.2358408 & 3.1263229 & 0.8974703 \\ \text { H } & 1.2044552 & -2.1773345 & 0.4656893\end{array}$




$\begin{array}{lrrr}\text { 1-E, RI-MP } / \text { SVP } & & \\ \text { C } & 2.1171109 & 0.9388356 & -0.3521395 \\ \mathrm{C} & 1.2635431 & -0.1373701 & -0.0506077 \\ \mathrm{C} & 1.8528196 & -1.5081153 & 0.2317059 \\ \mathrm{C} & -0.1106050 & 0.0687835 & -0.0538347 \\ \mathrm{C} & -1.0770270 & -0.9534651 & 0.1738767 \\ \mathrm{C} & -0.8381619 & 1.3835308 & -0.2389987 \\ \mathrm{C} & -2.3505917 & -0.4766944 & -0.0528837 \\ \mathrm{H} & -0.4320275 & 1.9537232 & -1.0879369 \\ \mathrm{C} & -2.2917322 & 0.9517283 & -0.5146780 \\ \mathrm{H} & -2.5268889 & 0.9963734 & -1.5904589 \\ \mathrm{H} & -3.0242242 & 1.5883006 & 0.0023910 \\ \mathrm{H} & -0.8496960 & -1.9803647 & 0.4613016 \\ \mathrm{H} & 1.4770467 & -2.2415029 & -0.5022833 \\ \mathrm{H} & 1.5112583 & -1.8698587 & 1.2158891 \\ \mathrm{~N} & 3.4317334 & 0.8095021 & -0.3743099 \\ \mathrm{C} & -3.5576002 & -1.2547966 & 0.0815712 \\ \mathrm{H} & -3.4476176 & -2.2897890 & 0.4149599 \\ \mathrm{C} & -4.7912729 & -0.7676613 & -0.1842368 \\ \mathrm{H} & -4.9447092 & 0.2575478 & -0.5245551 \\ \mathrm{H} & -5.6771624 & -1.3925140 & -0.0685276 \\ \mathrm{C} & 4.0776135 & -0.4101809 & -0.0870491 \\ \mathrm{H} & 5.1647277 & -0.3840335 & -0.1190069 \\ \mathrm{C} & 3.3547508 & -1.5043245 & 0.2026307 \\ \mathrm{H} & 3.8845688 & -2.4324017 & 0.4194162 \\ \mathrm{H} & 4.0022814 & 1.6172861 & -0.6096017 \\ \mathrm{C} & -0.7469881 & 2.2303736 & 1.0368348 \\ \mathrm{H} & -1.1692573 & 1.6755509 & 1.8856320 \\ \mathrm{H} & 0.2926913 & 2.4843362 & 1.2814120 \\ \mathrm{H} & -1.3113720 & 3.1639599 & 0.9165271 \\ \mathrm{H} & 1.7242469 & 1.9279897 & -0.5903841\end{array}$




\section{1-Z, RI-MP2/SVP}

$\begin{array}{rrrr}\mathrm{C} & 1.8483325 & -1.3360539 & 0.2742255 \\ \mathrm{C} & 1.2774585 & -0.0816085 & -0.0117249 \\ \mathrm{C} & 2.1846578 & 1.0856444 & -0.3615932 \\ \mathrm{C} & -0.1091916 & 0.0468401 & 0.0049162 \\ \mathrm{C} & -1.0983631 & -0.9570225 & 0.2514008 \\ \mathrm{C} & -0.8225247 & 1.3537068 & -0.2268209 \\ \mathrm{C} & -2.3541508 & -0.4752543 & -0.0359903 \\ \mathrm{H} & -0.3572941 & 1.9191725 & -1.0491028 \\ \mathrm{C} & -2.2647417 & 0.9328471 & -0.5550079 \\ \mathrm{H} & -2.4475619 & 0.9323774 & -1.6419026 \\ \mathrm{H} & -3.0126065 & 1.5973637 & -0.1000393 \\ \mathrm{H} & -0.9128020 & -1.9793219 & 0.5829794 \\ \mathrm{H} & 2.0847045 & 1.8918871 & 0.3831117 \\ \mathrm{H} & 1.8727461 & 1.5329385 & -1.3198999 \\ \mathrm{~N} & 3.1488676 & -1.5507345 & 0.2167837 \\ \mathrm{C} & -3.5757622 & -1.2364827 & 0.0838742 \\ \mathrm{H} & -3.4905084 & -2.2571889 & 0.4657979 \\ \mathrm{C} & -4.7915938 & -0.7511918 & -0.2528211 \\ \mathrm{H} & -4.9195431 & 0.2595973 & -0.6428939 \\ \mathrm{H} & -5.6883240 & -1.3620078 & -0.1470595 \\ \mathrm{C} & 4.0665297 & -0.5507058 & -0.1658139 \\ \mathrm{H} & 5.1074593 & -0.8627953 & -0.2144822 \\ \mathrm{C} & 3.6296335 & 0.6859818 & -0.4526135 \\ \mathrm{H} & 4.3612154 & 1.4374035 & -0.7514936 \\ \mathrm{H} & 3.5044133 & -2.4776276 & 0.4365800 \\ \mathrm{C} & -0.7819525 & 2.1981776 & 1.0568989 \\ \mathrm{H} & -1.2923626 & 1.6602658 & 1.8672439 \\ \mathrm{H} & 0.2428948 & 2.4152401 & 1.3814854 \\ \mathrm{H} & -1.2968669 & 3.1531903 & 0.8927588 \\ \mathrm{H} & 1.2325262 & -2.1918237 & 0.5530129\end{array}$


Cartesian coordinates for $\mathrm{S}_{1}$ MEP geometries of 1 (in $\AA$ )

1-E, CASSCF/cc-pVTZ, MEP point 1

$\begin{array}{rrrr}\text { C } & 2.120108 & 0.904367 & -0.362574 \\ \mathrm{C} & 1.304280 & -0.105642 & -0.038981 \\ \mathrm{C} & 1.845473 & -1.474119 & 0.274318 \\ \mathrm{C} & -0.160354 & 0.062065 & -0.030429 \\ \mathrm{C} & -1.059233 & -0.947353 & 0.132367 \\ \mathrm{C} & -0.868218 & 1.389641 & -0.223878 \\ \mathrm{C} & -2.396108 & -0.477038 & -0.045022 \\ \mathrm{H} & -0.488392 & 1.893916 & -1.105107 \\ \mathrm{C} & -2.339346 & 0.972221 & -0.442887 \\ \mathrm{H} & -2.619008 & 1.072334 & -1.486306 \\ \mathrm{H} & -3.025586 & 1.581623 & 0.129199 \\ \mathrm{H} & -0.824933 & -1.971667 & 0.337527 \\ \mathrm{H} & 1.423909 & -2.193893 & -0.427535 \\ \mathrm{H} & 1.492406 & -1.793495 & 1.254293 \\ \mathrm{~N} & 3.529909 & 0.739410 & -0.399647 \\ \mathrm{C} & -3.551807 & -1.271473 & 0.072214 \\ \mathrm{H} & -3.412549 & -2.297735 & 0.359878 \\ \mathrm{C} & -4.822722 & -0.828093 & -0.165781 \\ \mathrm{H} & -5.027832 & 0.181361 & -0.462791 \\ \mathrm{H} & -5.661514 & -1.486280 & -0.063350 \\ \mathrm{C} & 4.090144 & -0.415700 & -0.116196 \\ \mathrm{H} & 5.160179 & -0.460984 & -0.154972 \\ \mathrm{C} & 3.329851 & -1.525991 & 0.222489 \\ \mathrm{H} & 3.839544 & -2.438688 & 0.451570 \\ \mathrm{H} & 4.097659 & 1.522933 & -0.625422 \\ \mathrm{C} & -0.716392 & 2.322016 & 0.985658 \\ \mathrm{H} & -1.128067 & 1.861823 & 1.876243 \\ \mathrm{H} & 0.316488 & 2.570877 & 1.189880 \\ \mathrm{H} & -1.250110 & 3.246681 & 0.808171 \\ \mathrm{H} & 1.791585 & 1.887854 & -0.614210\end{array}$


1-E, CASSCF/cc-pVTZ, MEP point 2

$\begin{array}{lrrr}\mathrm{C} & 2.126409 & 0.888994 & -0.441243 \\ \mathrm{C} & 1.302785 & -0.099529 & -0.074039 \\ \mathrm{C} & 1.837564 & -1.452892 & 0.309549 \\ \mathrm{C} & -0.164484 & 0.067118 & -0.072090 \\ \mathrm{C} & -1.058578 & -0.953340 & 0.039994 \\ \mathrm{C} & -0.877947 & 1.400106 & -0.200389 \\ \mathrm{C} & -2.400051 & -0.480105 & -0.080240 \\ \mathrm{H} & -0.527611 & 1.925834 & -1.081777 \\ \mathrm{C} & -2.358710 & 0.992546 & -0.381938 \\ \mathrm{H} & -2.687976 & 1.166574 & -1.400597 \\ \mathrm{H} & -3.016903 & 1.558072 & 0.263877 \\ \mathrm{H} & -0.817887 & -1.986363 & 0.185277 \\ \mathrm{H} & 1.449854 & -2.198385 & -0.384992 \\ \mathrm{H} & 1.443476 & -1.740768 & 1.283411 \\ \mathrm{~N} & 3.537018 & 0.718250 & -0.447901 \\ \mathrm{C} & -3.548591 & -1.287151 & 0.029335 \\ \mathrm{H} & -3.392782 & -2.329448 & 0.240898 \\ \mathrm{C} & -4.830706 & -0.838439 & -0.120011 \\ \mathrm{H} & -5.054276 & 0.187353 & -0.337088 \\ \mathrm{H} & -5.660514 & -1.509109 & -0.025496 \\ \mathrm{C} & 4.091217 & -0.412895 & -0.069812 \\ \mathrm{H} & 5.162005 & -0.456440 & -0.073666 \\ \mathrm{C} & 3.322656 & -1.498773 & 0.322936 \\ \mathrm{H} & 3.825522 & -2.388571 & 0.640181 \\ \mathrm{H} & 4.110356 & 1.487568 & -0.706245 \\ \mathrm{C} & -0.678028 & 2.303610 & 1.022911 \\ \mathrm{H} & -1.053846 & 1.823731 & 1.919014 \\ \mathrm{H} & 0.362829 & 2.547840 & 1.189069 \\ \mathrm{H} & -1.217424 & 3.232193 & 0.888120 \\ \mathrm{H} & 1.804750 & 1.860658 & -0.744258\end{array}$


1-E, CASSCF/cc-pVTZ, MEP point 3

$\begin{array}{lrrr}\mathrm{C} & 2.118070 & 0.856014 & -0.545670 \\ \mathrm{C} & 1.298861 & -0.105654 & -0.105583 \\ \mathrm{C} & 1.839512 & -1.428920 & 0.367338 \\ \mathrm{C} & -0.169273 & 0.061581 & -0.098237 \\ \mathrm{C} & -1.064397 & -0.962035 & -0.033695 \\ \mathrm{C} & -0.878288 & 1.401299 & -0.158867 \\ \mathrm{C} & -2.405150 & -0.481058 & -0.106731 \\ \mathrm{H} & -0.553160 & 1.950893 & -1.035706 \\ \mathrm{C} & -2.367115 & 1.008786 & -0.308635 \\ \mathrm{H} & -2.738733 & 1.257571 & -1.296548 \\ \mathrm{H} & -2.995304 & 1.526833 & 0.403967 \\ \mathrm{H} & -0.823183 & -2.001699 & 0.053682 \\ \mathrm{H} & 1.491366 & -2.214590 & -0.303693 \\ \mathrm{H} & 1.412168 & -1.675344 & 1.338164 \\ \mathrm{~N} & 3.528949 & 0.692550 & -0.531575 \\ \mathrm{C} & -3.554228 & -1.292289 & -0.026139 \\ \mathrm{H} & -3.396941 & -2.346430 & 0.113466 \\ \mathrm{C} & -4.837126 & -0.832531 & -0.117273 \\ \mathrm{H} & -5.062012 & 0.205779 & -0.261641 \\ \mathrm{H} & -5.667012 & -1.506322 & -0.048823 \\ \mathrm{C} & 4.088062 & -0.390697 & -0.036556 \\ \mathrm{H} & 5.159093 & -0.418270 & -0.011005 \\ \mathrm{C} & 3.323498 & -1.445065 & 0.439507 \\ \mathrm{H} & 3.828145 & -2.287932 & 0.863982 \\ \mathrm{H} & 4.099795 & 1.443339 & -0.844575 \\ \mathrm{C} & -0.627819 & 2.267682 & 1.080913 \\ \mathrm{H} & -0.966505 & 1.761681 & 1.977562 \\ \mathrm{H} & 0.419740 & 2.506841 & 1.208427 \\ \mathrm{H} & -1.171190 & 3.199937 & 0.996553 \\ \mathrm{H} & 1.792674 & 1.803757 & -0.914293\end{array}$


1-E, CASSCF/cc-pVTZ, MEP point 4

$\begin{array}{lrrr}\mathrm{C} & 2.110025 & 0.812007 & -0.652200 \\ \mathrm{C} & 1.295801 & -0.111427 & -0.129823 \\ \mathrm{C} & 1.843498 & -1.393812 & 0.440819 \\ \mathrm{C} & -0.173867 & 0.056989 & -0.116565 \\ \mathrm{C} & -1.071234 & -0.966690 & -0.102424 \\ \mathrm{C} & -0.877752 & 1.400487 & -0.109897 \\ \mathrm{C} & -2.409877 & -0.480200 & -0.131633 \\ \mathrm{H} & -0.573149 & 1.976016 & -0.977738 \\ \mathrm{C} & -2.372200 & 1.019880 & -0.235646 \\ \mathrm{H} & -2.778094 & 1.338172 & -1.189199 \\ \mathrm{H} & -2.973257 & 1.486898 & 0.533765 \\ \mathrm{H} & -0.830545 & -2.010100 & -0.074398 \\ \mathrm{H} & 1.523927 & -2.224972 & -0.187891 \\ \mathrm{H} & 1.395409 & -1.586212 & 1.414175 \\ \mathrm{~N} & 3.520575 & 0.655507 & -0.622875 \\ \mathrm{C} & -3.561122 & -1.293033 & -0.084872 \\ \mathrm{H} & -3.404885 & -2.353948 & -0.011520 \\ \mathrm{C} & -4.842737 & -0.825845 & -0.130007 \\ \mathrm{H} & -5.066175 & 0.219853 & -0.207983 \\ \mathrm{H} & -5.673904 & -1.500434 & -0.090815 \\ \mathrm{C} & 4.085003 & -0.367985 & -0.017116 \\ \mathrm{H} & 5.155726 & -0.378594 & 0.025979 \\ \mathrm{C} & 3.325442 & -1.379432 & 0.548848 \\ \mathrm{H} & 3.831462 & -2.165268 & 1.069980 \\ \mathrm{H} & 4.088493 & 1.382840 & -0.992025 \\ \mathrm{C} & -0.584486 & 2.227352 & 1.146246 \\ \mathrm{H} & -0.898425 & 1.697070 & 2.037964 \\ \mathrm{H} & 0.468636 & 2.456139 & 1.245714 \\ \mathrm{H} & -1.123279 & 3.165213 & 1.106990 \\ \mathrm{H} & 1.780884 & 1.727766 & -1.092178\end{array}$


1-E, CASSCF/cc-pVTZ, MEP point 5

$\begin{array}{rrrr}\text { C } & 2.103768 & 0.758155 & -0.755026 \\ \mathrm{C} & 1.293614 & -0.116098 & -0.148792 \\ \mathrm{C} & 1.847812 & -1.346787 & 0.523516 \\ \mathrm{C} & -0.177899 & 0.053754 & -0.132298 \\ \mathrm{C} & -1.078300 & -0.966742 & -0.176206 \\ \mathrm{C} & -0.876503 & 1.397884 & -0.057908 \\ \mathrm{C} & -2.414060 & -0.477556 & -0.160657 \\ \mathrm{H} & -0.587197 & 2.000448 & -0.912942 \\ \mathrm{C} & -2.374884 & 1.026431 & -0.168223 \\ \mathrm{H} & -2.806704 & 1.408891 & -1.085941 \\ \mathrm{H} & -2.953589 & 1.440464 & 0.647604 \\ \mathrm{H} & -0.838500 & -2.010529 & -0.212011 \\ \mathrm{H} & 1.543630 & -2.223394 & -0.048037 \\ \mathrm{H} & 1.389735 & -1.474635 & 1.502642 \\ \mathrm{~N} & 3.512265 & 0.610479 & -0.708777 \\ \mathrm{C} & -3.567866 & -1.290326 & -0.143506 \\ \mathrm{H} & -3.412816 & -2.353942 & -0.137063 \\ \mathrm{C} & -4.847690 & -0.819321 & -0.139877 \\ \mathrm{H} & -5.069486 & 0.229588 & -0.151786 \\ \mathrm{H} & -5.680144 & -1.493380 & -0.128117 \\ \mathrm{C} & 4.082823 & -0.347409 & -0.005648 \\ \mathrm{H} & 5.153002 & -0.339992 & 0.047563 \\ \mathrm{C} & 3.328467 & -1.307742 & 0.645337 \\ \mathrm{H} & 3.835086 & -2.029893 & 1.251084 \\ \mathrm{H} & 4.077534 & 1.310810 & -1.130924 \\ \mathrm{C} & -0.549615 & 2.184385 & 1.214516 \\ \mathrm{H} & -0.840331 & 1.627856 & 2.098182 \\ \mathrm{H} & 0.506603 & 2.409136 & 1.290422 \\ \mathrm{H} & -1.086979 & 3.123882 & 1.218633 \\ \mathrm{H} & 1.770654 & 1.631401 & -1.272453\end{array}$


1-E, CASSCF/cc-pVTZ, MEP point 6

$\begin{array}{rrrr}\text { C } & 2.100049 & 0.701969 & -0.843302 \\ \mathrm{C} & 1.292365 & -0.119677 & -0.163452 \\ \mathrm{C} & 1.851373 & -1.293506 & 0.602109 \\ \mathrm{C} & -0.181111 & 0.052721 & -0.146561 \\ \mathrm{C} & -1.084278 & -0.961843 & -0.247062 \\ \mathrm{C} & -0.875476 & 1.394426 & -0.010502 \\ \mathrm{C} & -2.417427 & -0.473442 & -0.189910 \\ \mathrm{H} & -0.596770 & 2.022463 & -0.851033 \\ \mathrm{C} & -2.376365 & 1.028958 & -0.112478 \\ \mathrm{H} & -2.827060 & 1.465315 & -0.996501 \\ \mathrm{H} & -2.937804 & 1.393562 & 0.738412 \\ \mathrm{H} & -0.844906 & -2.002618 & -0.339836 \\ \mathrm{H} & 1.550092 & -2.209786 & 0.095274 \\ \mathrm{H} & 1.392268 & -1.352489 & 1.587176 \\ \mathrm{~N} & 3.504946 & 0.565938 & -0.778142 \\ \mathrm{C} & -3.573317 & -1.285643 & -0.194628 \\ \mathrm{H} & -3.419659 & -2.348330 & -0.245469 \\ \mathrm{C} & -4.851152 & -0.814599 & -0.144848 \\ \mathrm{H} & -5.071404 & 0.233801 & -0.099561 \\ \mathrm{H} & -5.684598 & -1.487554 & -0.153016 \\ \mathrm{C} & 4.081756 & -0.331985 & 0.000291 \\ \mathrm{H} & 5.151446 & -0.310353 & 0.056020 \\ \mathrm{C} & 3.332037 & -1.241018 & 0.721232 \\ \mathrm{H} & 3.839057 & -1.907260 & 1.388067 \\ \mathrm{H} & 4.068440 & 1.238306 & -1.246521 \\ \mathrm{C} & -0.524905 & 2.142759 & 1.277244 \\ \mathrm{H} & -0.802220 & 1.563152 & 2.150256 \\ \mathrm{H} & 0.533542 & 2.362266 & 1.339486 \\ \mathrm{H} & -1.058122 & 3.083868 & 1.317095 \\ \mathrm{H} & 1.763672 & 1.530032 & -1.429148\end{array}$


1-E, CASSCF/cc-pVTZ, MEP point 7

$\begin{array}{rrrr}\text { C } & 2.096753 & 0.631338 & -0.933283 \\ \mathrm{C} & 1.290129 & -0.123726 & -0.175626 \\ \mathrm{C} & 1.855234 & -1.224122 & 0.688926 \\ \mathrm{C} & -0.183884 & 0.052791 & -0.161894 \\ \mathrm{C} & -1.090563 & -0.950585 & -0.330575 \\ \mathrm{C} & -0.874109 & 1.388604 & 0.042294 \\ \mathrm{C} & -2.420375 & -0.467031 & -0.223923 \\ \mathrm{H} & -0.606065 & 2.043034 & -0.781834 \\ \mathrm{C} & -2.377040 & 1.028067 & -0.053053 \\ \mathrm{H} & -2.844962 & 1.519929 & -0.897842 \\ \mathrm{H} & -2.921313 & 1.336913 & 0.830592 \\ \mathrm{H} & -0.851802 & -1.983716 & -0.490557 \\ \mathrm{H} & 1.550643 & -2.178555 & 0.261159 \\ \mathrm{H} & 1.400221 & -1.202753 & 1.677476 \\ \mathrm{~N} & 3.494225 & 0.512020 & -0.847319 \\ \mathrm{C} & -3.578050 & -1.278531 & -0.249598 \\ \mathrm{H} & -3.426052 & -2.336527 & -0.363864 \\ \mathrm{C} & -4.853329 & -0.811876 & -0.146866 \\ \mathrm{H} & -5.071879 & 0.232313 & -0.038996 \\ \mathrm{H} & -5.687318 & -1.483583 & -0.176273 \\ \mathrm{C} & 4.080517 & -0.317827 & 0.004047 \\ \mathrm{H} & 5.149680 & -0.280905 & 0.056104 \\ \mathrm{C} & 3.337271 & -1.164649 & 0.795461 \\ \mathrm{H} & 3.845875 & -1.770853 & 1.516112 \\ \mathrm{H} & 4.055430 & 1.149151 & -1.365827 \\ \mathrm{C} & -0.501190 & 2.097967 & 1.344198 \\ \mathrm{H} & -0.762745 & 1.494045 & 2.205710 \\ \mathrm{H} & 0.558582 & 2.316445 & 1.392281 \\ \mathrm{H} & -1.032577 & 3.037774 & 1.421133 \\ \mathrm{H} & 1.756151 & 1.400941 & -1.592359\end{array}$


1-E, CASSCF/cc-pVTZ, MEP point 8

$\begin{array}{lrrc}\mathrm{C} & 2.094972 & 0.551131 & -1.016910 \\ \mathrm{C} & 1.287163 & -0.128996 & -0.184729 \\ \mathrm{C} & 1.859759 & -1.141357 & 0.775877 \\ \mathrm{C} & -0.185684 & 0.054312 & -0.178201 \\ \mathrm{C} & -1.096405 & -0.932443 & -0.417384 \\ \mathrm{C} & -0.872359 & 1.380976 & 0.096091 \\ \mathrm{C} & -2.422951 & -0.458207 & -0.260831 \\ \mathrm{H} & -0.614308 & 2.062614 & -0.709281 \\ \mathrm{C} & -2.376930 & 1.023815 & 0.003984 \\ \mathrm{H} & -2.859425 & 1.569053 & -0.798940 \\ \mathrm{H} & -2.905516 & 1.274715 & 0.915152 \\ \mathrm{H} & -0.857695 & -1.953591 & -0.643260 \\ \mathrm{H} & 1.545317 & -2.128492 & 0.439534 \\ \mathrm{H} & 1.415759 & -1.029759 & 1.763072 \\ \mathrm{~N} & 3.479429 & 0.454960 & -0.910227 \\ \mathrm{C} & -3.582013 & -1.269180 & -0.304358 \\ \mathrm{H} & -3.432302 & -2.318942 & -0.481696 \\ \mathrm{C} & -4.854185 & -0.811538 & -0.146717 \\ \mathrm{H} & -5.070792 & 0.224577 & 0.024834 \\ \mathrm{H} & -5.688436 & -1.481975 & -0.193670 \\ \mathrm{C} & 4.079957 & -0.307354 & 0.005817 \\ \mathrm{H} & 5.148645 & -0.258275 & 0.045515 \\ \mathrm{C} & 3.344377 & -1.085510 & 0.860516 \\ \mathrm{H} & 3.854788 & -1.639271 & 1.621431 \\ \mathrm{H} & 4.038328 & 1.049179 & -1.480923 \\ \mathrm{C} & -0.481174 & 2.050558 & 1.411983 \\ \mathrm{H} & -0.732616 & 1.424077 & 2.260167 \\ \mathrm{H} & 0.579839 & 2.266654 & 1.451467 \\ \mathrm{H} & -1.008646 & 2.989358 & 1.522480 \\ \mathrm{H} & 1.747811 & 1.253204 & -1.744970\end{array}$


1-E, CASSCF/cc-pVTZ, MEP point 9

$\begin{array}{rrrr}\mathrm{C} & 2.093876 & 0.465336 & -1.089523 \\ \mathrm{C} & 1.281866 & -0.137233 & -0.188860 \\ \mathrm{C} & 1.865575 & -1.047873 & 0.859790 \\ \mathrm{C} & -0.185604 & 0.056713 & -0.193442 \\ \mathrm{C} & -1.101670 & -0.907822 & -0.503889 \\ \mathrm{C} & -0.870088 & 1.371447 & 0.149459 \\ \mathrm{C} & -2.424595 & -0.446626 & -0.300967 \\ \mathrm{H} & -0.623020 & 2.079189 & -0.636940 \\ \mathrm{C} & -2.375795 & 1.015879 & 0.060573 \\ \mathrm{H} & -2.872878 & 1.614387 & -0.693646 \\ \mathrm{H} & -2.886620 & 1.203715 & 0.996932 \\ \mathrm{H} & -0.863475 & -1.913440 & -0.792905 \\ \mathrm{H} & 1.537955 & -2.060098 & 0.626171 \\ \mathrm{H} & 1.438033 & -0.838263 & 1.837836 \\ \mathrm{~N} & 3.458020 & 0.393799 & -0.969898 \\ \mathrm{C} & -3.584645 & -1.257325 & -0.360120 \\ \mathrm{H} & -3.437754 & -2.295442 & -0.598334 \\ \mathrm{C} & -4.853141 & -0.813891 & -0.146382 \\ \mathrm{H} & -5.067911 & 0.210908 & 0.084936 \\ \mathrm{H} & -5.686853 & -1.483548 & -0.210183 \\ \mathrm{C} & 4.079165 & -0.300483 & 0.006212 \\ \mathrm{H} & 5.147429 & -0.243160 & 0.023417 \\ \mathrm{C} & 3.353848 & -1.003849 & 0.916884 \\ \mathrm{H} & 3.867605 & -1.510795 & 1.707526 \\ \mathrm{H} & 4.013629 & 0.939070 & -1.591708 \\ \mathrm{C} & -0.463211 & 2.002970 & 1.477687 \\ \mathrm{H} & -0.700755 & 1.352762 & 2.312036 \\ \mathrm{H} & 0.597693 & 2.223676 & 1.508646 \\ \mathrm{H} & -0.991900 & 2.936395 & 1.622335 \\ \mathrm{H} & 1.736310 & 1.091754 & -1.879572\end{array}$


1-E, CASSCF/cc-pVTZ, MEP point 10

$\begin{array}{lrrc}\mathrm{C} & 2.092282 & 0.380440 & -1.148983 \\ \mathrm{C} & 1.274829 & -0.144708 & -0.185811 \\ \mathrm{C} & 1.872934 & -0.945241 & 0.938382 \\ \mathrm{C} & -0.183769 & 0.060092 & -0.206652 \\ \mathrm{C} & -1.105797 & -0.881841 & -0.575603 \\ \mathrm{C} & -0.867797 & 1.360754 & 0.200158 \\ \mathrm{C} & -2.425375 & -0.433171 & -0.340382 \\ \mathrm{H} & -0.633865 & 2.095647 & -0.565231 \\ \mathrm{C} & -2.373970 & 1.003745 & 0.117028 \\ \mathrm{H} & -2.888724 & 1.652542 & -0.581235 \\ \mathrm{H} & -2.862737 & 1.124389 & 1.076356 \\ \mathrm{H} & -0.867879 & -1.871251 & -0.917006 \\ \mathrm{H} & 1.530118 & -1.972242 & 0.820141 \\ \mathrm{H} & 1.468682 & -0.628659 & 1.896435 \\ \mathrm{~N} & 3.432343 & 0.326854 & -1.030207 \\ \mathrm{C} & -3.587398 & -1.241361 & -0.423100 \\ \mathrm{H} & -3.445065 & -2.262695 & -0.728045 \\ \mathrm{C} & -4.851192 & -0.817661 & -0.151595 \\ \mathrm{H} & -5.063085 & 0.189703 & 0.148479 \\ \mathrm{H} & -5.684243 & -1.485924 & -0.235146 \\ \mathrm{C} & 4.078861 & -0.297569 & 0.002078 \\ \mathrm{H} & 5.146502 & -0.241991 & -0.012741 \\ \mathrm{C} & 3.364829 & -0.918169 & 0.964920 \\ \mathrm{H} & 3.883358 & -1.381624 & 1.779337 \\ \mathrm{H} & 3.984228 & 0.803580 & -1.710380 \\ \mathrm{C} & -0.446589 & 1.952289 & 1.541377 \\ \mathrm{H} & -0.667903 & 1.275811 & 2.359276 \\ \mathrm{H} & 0.612933 & 2.182723 & 1.565543 \\ \mathrm{H} & -0.980438 & 2.876429 & 1.722490 \\ \mathrm{H} & 1.719659 & 0.924060 & -1.992384\end{array}$


1-E, CASSCF/cc-pVTZ, MEP point 11

$\begin{array}{rrrr}\text { C } & 2.085043 & 0.310866 & -1.190729 \\ \mathrm{C} & 1.270206 & -0.139195 & -0.173581 \\ \mathrm{C} & 1.886080 & -0.833590 & 1.008472 \\ \mathrm{C} & -0.182503 & 0.064556 & -0.207249 \\ \mathrm{C} & -1.106602 & -0.867546 & -0.601540 \\ \mathrm{C} & -0.869061 & 1.351562 & 0.245645 \\ \mathrm{C} & -2.425906 & -0.422978 & -0.366552 \\ \mathrm{H} & -0.651242 & 2.114357 & -0.496912 \\ \mathrm{C} & -2.373965 & 0.986120 & 0.175024 \\ \mathrm{H} & -2.913880 & 1.675085 & -0.462449 \\ \mathrm{H} & -2.833704 & 1.039873 & 1.155016 \\ \mathrm{H} & -0.867634 & -1.844052 & -0.978017 \\ \mathrm{H} & 1.525995 & -1.861207 & 1.015092 \\ \mathrm{H} & 1.513574 & -0.404911 & 1.933931 \\ \mathrm{~N} & 3.410023 & 0.245082 & -1.095944 \\ \mathrm{C} & -3.591986 & -1.219664 & -0.499944 \\ \mathrm{H} & -3.453331 & -2.219258 & -0.872058 \\ \mathrm{C} & -4.852743 & -0.818271 & -0.184191 \\ \mathrm{H} & -5.061640 & 0.165271 & 0.188727 \\ \mathrm{H} & -5.686261 & -1.480368 & -0.303949 \\ \mathrm{C} & 4.081036 & -0.304341 & -0.020090 \\ \mathrm{H} & 5.147901 & -0.269450 & -0.073125 \\ \mathrm{C} & 3.380031 & -0.828187 & 1.000288 \\ \mathrm{H} & 3.908122 & -1.245626 & 1.833266 \\ \mathrm{H} & 3.954499 & 0.631303 & -1.838258 \\ \mathrm{C} & -0.434624 & 1.898652 & 1.602171 \\ \mathrm{H} & -0.633069 & 1.188678 & 2.397424 \\ \mathrm{H} & 0.621101 & 2.147988 & 1.619575 \\ \mathrm{H} & -0.980258 & 2.806016 & 1.827400 \\ \mathrm{H} & 1.695734 & 0.777699 & -2.072081\end{array}$


1-E, CASSCF/cc-pVTZ, MEP point 12

$\begin{array}{rrrr}\mathrm{C} & 2.062640 & 0.265581 & -1.209354 \\ \mathrm{C} & 1.271995 & -0.121507 & -0.143609 \\ \mathrm{C} & 1.919783 & -0.732841 & 1.066348 \\ \mathrm{C} & -0.181864 & 0.066161 & -0.167776 \\ \mathrm{C} & -1.099131 & -0.872159 & -0.564097 \\ \mathrm{C} & -0.878245 & 1.345989 & 0.291118 \\ \mathrm{C} & -2.422895 & -0.425446 & -0.361378 \\ \mathrm{H} & -0.669533 & 2.120388 & -0.442025 \\ \mathrm{C} & -2.379779 & 0.966756 & 0.224145 \\ \mathrm{H} & -2.938182 & 1.672386 & -0.377657 \\ \mathrm{H} & -2.823167 & 0.978529 & 1.213507 \\ \mathrm{H} & -0.852448 & -1.844747 & -0.945813 \\ \mathrm{H} & 1.538801 & -1.745780 & 1.183780 \\ \mathrm{H} & 1.596914 & -0.211116 & 1.961638 \\ \mathrm{~N} & 3.383273 & 0.165961 & -1.163197 \\ \mathrm{C} & -3.590387 & -1.202721 & -0.572482 \\ \mathrm{H} & -3.447189 & -2.186100 & -0.984416 \\ \mathrm{C} & -4.858341 & -0.804861 & -0.281148 \\ \mathrm{H} & -5.072177 & 0.161296 & 0.132420 \\ \mathrm{H} & -5.692389 & -1.452432 & -0.461227 \\ \mathrm{C} & 4.085836 & -0.328530 & -0.075486 \\ \mathrm{H} & 5.149801 & -0.328534 & -0.174952 \\ \mathrm{C} & 3.412621 & -0.762848 & 1.001986 \\ \mathrm{H} & 3.962237 & -1.142575 & 1.839213 \\ \mathrm{H} & 3.906820 & 0.479913 & -1.953593 \\ \mathrm{C} & -0.445426 & 1.875286 & 1.655878 \\ \mathrm{H} & -0.621954 & 1.144145 & 2.437124 \\ \mathrm{H} & 0.604013 & 2.149869 & 1.670929 \\ \mathrm{H} & -1.010188 & 2.764588 & 1.904870 \\ \mathrm{H} & 1.647570 & 0.678853 & -2.105706\end{array}$


1-E, CASSCF/cc-pVTZ, MEP point 13

$\begin{array}{rrrr}\text { C } & 2.024429 & 0.231123 & -1.211547 \\ \mathrm{C} & 1.276037 & -0.107811 & -0.098823 \\ \mathrm{C} & 1.971527 & -0.659889 & 1.112677 \\ \mathrm{C} & -0.180280 & 0.061497 & -0.094558 \\ \mathrm{C} & -1.087048 & -0.885558 & -0.493763 \\ \mathrm{C} & -0.889303 & 1.343498 & 0.337258 \\ \mathrm{C} & -2.415929 & -0.435082 & -0.337903 \\ \mathrm{H} & -0.675793 & 2.111389 & -0.401647 \\ \mathrm{C} & -2.387735 & 0.954451 & 0.254922 \\ \mathrm{H} & -2.947071 & 1.660827 & -0.344809 \\ \mathrm{H} & -2.837447 & 0.955250 & 1.241728 \\ \mathrm{H} & -0.829766 & -1.858921 & -0.866524 \\ \mathrm{H} & 1.575680 & -1.652638 & 1.318057 \\ \mathrm{H} & 1.707613 & -0.071734 & 1.986408 \\ \mathrm{~N} & 3.342930 & 0.109343 & -1.223151 \\ \mathrm{C} & -3.577350 & -1.195467 & -0.627053 \\ \mathrm{H} & -3.420348 & -2.177750 & -1.03654 \\ \mathrm{C} & -4.856851 & -0.781508 & -0.419817 \\ \mathrm{H} & -5.084889 & 0.184042 & -0.012526 \\ \mathrm{H} & -5.685477 & -1.416374 & -0.660173 \\ \mathrm{C} & 4.087417 & -0.357917 & -0.150784 \\ \mathrm{H} & 5.144802 & -0.389492 & -0.302034 \\ \mathrm{C} & 3.458603 & -0.729255 & 0.975669 \\ \mathrm{H} & 4.040167 & -1.089578 & 1.799762 \\ \mathrm{H} & 3.833371 & 0.375159 & -2.051615 \\ \mathrm{C} & -0.477518 & 1.887756 & 1.702906 \\ \mathrm{H} & -0.648029 & 1.157030 & 2.485883 \\ \mathrm{H} & 0.566839 & 2.180442 & 1.725462 \\ \mathrm{H} & -1.059584 & 2.768453 & 1.942590 \\ \mathrm{H} & 1.573678 & 0.610840 & -2.105449\end{array}$


1-E, CASSCF/cc-pVTZ, MEP point 14

$\begin{array}{rrrr}\text { C } & 1.978634 & 0.195217 & -1.208450 \\ \mathrm{C} & 1.279198 & -0.101788 & -0.051918 \\ \mathrm{C} & 2.027868 & -0.598553 & 1.151257 \\ \mathrm{C} & -0.178725 & 0.051034 & -0.013653 \\ \mathrm{C} & -1.076969 & -0.903314 & -0.414564 \\ \mathrm{C} & -0.896509 & 1.339262 & 0.382483 \\ \mathrm{C} & -2.408260 & -0.444826 & -0.311089 \\ \mathrm{H} & -0.667688 & 2.097015 & -0.362581 \\ \mathrm{C} & -2.393050 & 0.948414 & 0.273512 \\ \mathrm{H} & -2.941755 & 1.651658 & -0.339436 \\ \mathrm{H} & -2.860541 & 0.953098 & 1.252059 \\ \mathrm{H} & -0.811261 & -1.880004 & -0.772431 \\ \mathrm{H} & 1.630978 & -1.571375 & 1.434189 \\ \mathrm{H} & 1.817509 & 0.043137 & 2.002073 \\ \mathrm{~N} & 3.293249 & 0.060442 & -1.278611 \\ \mathrm{C} & -3.559397 & -1.189015 & -0.672832 \\ \mathrm{H} & -3.390292 & -2.177217 & -1.063012 \\ \mathrm{C} & -4.843382 & -0.750838 & -0.565927 \\ \mathrm{H} & -5.084093 & 0.222009 & -0.183888 \\ \mathrm{H} & -5.662840 & -1.373731 & -0.862458 \\ \mathrm{C} & 4.083070 & -0.378713 & -0.226816 \\ \mathrm{H} & 5.131180 & -0.433275 & -0.428062 \\ \mathrm{C} & 3.505423 & -0.697173 & 0.942373 \\ \mathrm{H} & 4.122315 & -1.036322 & 1.749696 \\ \mathrm{H} & 3.745122 & 0.286141 & -2.140246 \\ \mathrm{C} & -0.513372 & 1.901692 & 1.749260 \\ \mathrm{H} & -0.692825 & 1.178081 & 2.536661 \\ \mathrm{H} & 0.528527 & 2.201233 & 1.787071 \\ \mathrm{H} & -1.104972 & 2.781462 & 1.968538 \\ \mathrm{H} & 1.487742 & 0.541968 & -2.094612\end{array}$


1-E, CASSCF/cc-pVTZ, MEP point 15

$\begin{array}{rrrr}\text { C } & 2.008928 & 0.222129 & -1.217832 \\ \mathrm{C} & 1.270809 & -0.110822 & -0.070866 \\ \mathrm{C} & 2.003294 & -0.637797 & 1.126046 \\ \mathrm{C} & -0.184524 & 0.048060 & -0.049683 \\ \mathrm{C} & -1.087351 & -0.896250 & -0.463142 \\ \mathrm{C} & -0.896166 & 1.336853 & 0.356200 \\ \mathrm{C} & -2.417100 & -0.441027 & -0.328583 \\ \mathrm{H} & -0.688966 & 2.087310 & -0.402607 \\ \mathrm{C} & -2.392504 & 0.939544 & 0.285119 \\ \mathrm{H} & -2.964719 & 1.653116 & -0.293000 \\ \mathrm{H} & -2.827881 & 0.917727 & 1.278367 \\ \mathrm{H} & -0.827498 & -1.868459 & -0.837221 \\ \mathrm{H} & 1.613098 & -1.624618 & 1.370955 \\ \mathrm{H} & 1.769179 & -0.031011 & 1.997071 \\ \mathrm{~N} & 3.329814 & 0.094085 & -1.240759 \\ \mathrm{C} & -3.575310 & -1.189328 & -0.657887 \\ \mathrm{H} & -3.413771 & -2.168262 & -1.073462 \\ \mathrm{C} & -4.857323 & -0.767059 & -0.485727 \\ \mathrm{H} & -5.090394 & 0.195351 & -0.073773 \\ \mathrm{H} & -5.682970 & -1.392828 & -0.757909 \\ \mathrm{C} & 4.084198 & -0.366421 & -0.173904 \\ \mathrm{H} & 5.139352 & -0.410041 & -0.337911 \\ \mathrm{C} & 3.481250 & -0.717242 & 0.952557 \\ \mathrm{H} & 4.075098 & -1.073456 & 1.770619 \\ \mathrm{H} & 3.812531 & 0.347527 & -2.075856 \\ \mathrm{C} & -0.481245 & 1.915240 & 1.706390 \\ \mathrm{H} & -0.640915 & 1.201102 & 2.506881 \\ \mathrm{H} & 0.560846 & 2.217005 & 1.715905 \\ \mathrm{H} & -1.068726 & 2.796637 & 1.929997 \\ \mathrm{H} & 1.541240 & 0.592257 & -2.106186\end{array}$


1-E, CASSCF/cc-pVTZ, MEP point 16

$\begin{array}{rrrr}\text { C } & 1.994654 & 0.208755 & -1.218995 \\ \mathrm{C} & 1.272721 & -0.106658 & -0.056316 \\ \mathrm{C} & 2.021966 & -0.615290 & 1.137954 \\ \mathrm{C} & -0.182925 & 0.047974 & -0.024913 \\ \mathrm{C} & -1.082848 & -0.900198 & -0.436316 \\ \mathrm{C} & -0.897083 & 1.337984 & 0.371881 \\ \mathrm{C} & -2.413290 & -0.442202 & -0.320854 \\ \mathrm{H} & -0.674821 & 2.091689 & -0.379183 \\ \mathrm{C} & -2.393994 & 0.945965 & 0.275744 \\ \mathrm{H} & -2.950572 & 1.654150 & -0.324133 \\ \mathrm{H} & -2.850212 & 0.940407 & 1.259701 \\ \mathrm{H} & -0.819906 & -1.875235 & -0.800846 \\ \mathrm{H} & 1.631582 & -1.595321 & 1.407916 \\ \mathrm{H} & 1.804964 & 0.008965 & 2.001060 \\ \mathrm{~N} & 3.313992 & 0.074098 & -1.261240 \\ \mathrm{C} & -3.567918 & -1.189141 & -0.665755 \\ \mathrm{H} & -3.402148 & -2.173937 & -1.065775 \\ \mathrm{C} & -4.851345 & -0.758031 & -0.529045 \\ \mathrm{H} & -5.088534 & 0.211241 & -0.136043 \\ \mathrm{H} & -5.673747 & -1.382579 & -0.813558 \\ \mathrm{C} & 4.083163 & -0.374390 & -0.199403 \\ \mathrm{H} & 5.135400 & -0.426573 & -0.379475 \\ \mathrm{C} & 3.496712 & -0.704514 & 0.941650 \\ \mathrm{H} & 4.102203 & -1.051705 & 1.755009 \\ \mathrm{H} & 3.784078 & 0.309965 & -2.108632 \\ \mathrm{C} & -0.502584 & 1.907253 & 1.732349 \\ \mathrm{H} & -0.675445 & 1.187775 & 2.525122 \\ \mathrm{H} & 0.539591 & 2.207594 & 1.760002 \\ \mathrm{H} & -1.092309 & 2.787983 & 1.952473 \\ \mathrm{H} & 1.513809 & 0.565112 & -2.105951\end{array}$


1-E, CASSCF/cc-pVTZ, MEP point 17

$\begin{array}{rrrr}\text { C } & 1.947699 & 0.166556 & -1.217808 \\ \mathrm{C} & 1.275736 & -0.103189 & -0.013257 \\ \mathrm{C} & 2.076694 & -0.555230 & 1.169760 \\ \mathrm{C} & -0.180464 & 0.038393 & 0.051231 \\ \mathrm{C} & -1.074287 & -0.917306 & -0.356741 \\ \mathrm{C} & -0.900018 & 1.334487 & 0.416502 \\ \mathrm{C} & -2.404523 & -0.449224 & -0.294661 \\ \mathrm{H} & -0.649148 & 2.085634 & -0.328089 \\ \mathrm{C} & -2.395875 & 0.950533 & 0.274039 \\ \mathrm{H} & -2.924281 & 1.649569 & -0.361105 \\ \mathrm{H} & -2.888160 & 0.969842 & 1.240091 \\ \mathrm{H} & -0.805224 & -1.897665 & -0.702044 \\ \mathrm{H} & 1.695297 & -1.515955 & 1.511882 \\ \mathrm{H} & 1.904679 & 0.117371 & 2.006696 \\ \mathrm{~N} & 3.262091 & 0.022536 & -1.314980 \\ \mathrm{C} & -3.547664 & -1.182771 & -0.700812 \\ \mathrm{H} & -3.373768 & -2.177734 & -1.071053 \\ \mathrm{C} & -4.828537 & -0.724497 & -0.666051 \\ \mathrm{H} & -5.073932 & 0.256319 & -0.308367 \\ \mathrm{H} & -5.640926 & -1.339518 & -0.996493 \\ \mathrm{C} & 4.076310 & -0.388511 & -0.270883 \\ \mathrm{H} & 5.118680 & -0.457876 & -0.496676 \\ \mathrm{C} & 3.540735 & -0.664380 & 0.908558 \\ \mathrm{H} & 4.180799 & -0.983079 & 1.707043 \\ \mathrm{H} & 3.693349 & 0.216445 & -2.193152 \\ \mathrm{C} & -0.547002 & 1.902841 & 1.789209 \\ \mathrm{H} & -0.744300 & 1.182113 & 2.574989 \\ \mathrm{H} & 0.494010 & 2.202115 & 1.849336 \\ \mathrm{H} & -1.142512 & 2.783975 & 1.991763 \\ \mathrm{H} & 1.427366 & 0.486761 & -2.096190\end{array}$


1-Z, CASSCF/cc-pVTZ, MEP point 1

$\begin{array}{rrrr}\mathrm{C} & 1.839917 & -1.318344 & 0.286573 \\ \mathrm{C} & 1.315181 & -0.118794 & 0.012857 \\ \mathrm{C} & 2.195057 & 1.040075 & -0.387097 \\ \mathrm{C} & -0.156883 & 0.069956 & 0.021295 \\ \mathrm{C} & -1.077643 & -0.922010 & 0.208904 \\ \mathrm{C} & -0.858676 & 1.398305 & -0.205586 \\ \mathrm{C} & -2.393296 & -0.458525 & -0.033529 \\ \mathrm{H} & -0.441559 & 1.922255 & -1.054931 \\ \mathrm{C} & -2.313014 & 0.967197 & -0.501197 \\ \mathrm{H} & -2.517170 & 1.004061 & -1.566519 \\ \mathrm{H} & -3.038193 & 1.605347 & -0.015320 \\ \mathrm{H} & -0.868605 & -1.942371 & 0.457380 \\ \mathrm{H} & 2.062757 & 1.866308 & 0.305734 \\ \mathrm{H} & 1.881097 & 1.425897 & -1.354633 \\ \mathrm{~N} & 3.237267 & -1.568960 & 0.209181 \\ \mathrm{C} & -3.556034 & -1.253540 & 0.072885 \\ \mathrm{H} & -3.426847 & -2.262464 & 0.420135 \\ \mathrm{C} & -4.809186 & -0.829498 & -0.251630 \\ \mathrm{H} & -4.999157 & 0.162278 & -0.611698 \\ \mathrm{H} & -5.652115 & -1.483868 & -0.158070 \\ \mathrm{C} & 4.074490 & -0.621343 & -0.145261 \\ \mathrm{H} & 5.113225 & -0.880846 & -0.194817 \\ \mathrm{C} & 3.635381 & 0.660755 & -0.445530 \\ \mathrm{H} & 4.362912 & 1.388867 & -0.738393 \\ \mathrm{H} & 3.573463 & -2.480566 & 0.414287 \\ \mathrm{C} & -0.791034 & 2.316861 & 1.021668 \\ \mathrm{H} & -1.246996 & 1.841644 & 1.882446 \\ \mathrm{H} & 0.224656 & 2.577717 & 1.286144 \\ \mathrm{H} & -1.324527 & 3.237579 & 0.823000 \\ \mathrm{H} & 1.268947 & -2.175591 & 0.563870\end{array}$


1-Z, CASSCF/cc-pVTZ, MEP point 2

$\begin{array}{rrrr}\mathrm{C} & 1.866442 & -1.302501 & 0.366884 \\ \mathrm{C} & 1.317010 & -0.135493 & 0.009323 \\ \mathrm{C} & 2.179352 & 1.007111 & -0.465886 \\ \mathrm{C} & -0.161084 & 0.053425 & -0.005567 \\ \mathrm{C} & -1.084720 & -0.944461 & 0.107864 \\ \mathrm{C} & -0.859999 & 1.397047 & -0.172402 \\ \mathrm{C} & -2.405656 & -0.457934 & -0.072509 \\ \mathrm{H} & -0.448533 & 1.940062 & -1.013074 \\ \mathrm{C} & -2.323791 & 0.989984 & -0.463774 \\ \mathrm{H} & -2.547203 & 1.084152 & -1.521736 \\ \mathrm{H} & -3.035002 & 1.606817 & 0.068004 \\ \mathrm{H} & -0.873078 & -1.980912 & 0.276628 \\ \mathrm{H} & 2.028875 & 1.872250 & 0.173557 \\ \mathrm{H} & 1.859125 & 1.326491 & -1.456056 \\ \mathrm{~N} & 3.268634 & -1.537678 & 0.285883 \\ \mathrm{C} & -3.571081 & -1.248223 & 0.035475 \\ \mathrm{H} & -3.435823 & -2.273991 & 0.326640 \\ \mathrm{C} & -4.834321 & -0.805611 & -0.221466 \\ \mathrm{H} & -5.034692 & 0.202847 & -0.525259 \\ \mathrm{H} & -5.675019 & -1.463161 & -0.129371 \\ \mathrm{C} & 4.090016 & -0.600714 & -0.132307 \\ \mathrm{H} & 5.131739 & -0.848296 & -0.179292 \\ \mathrm{C} & 3.626681 & 0.652914 & -0.502365 \\ \mathrm{H} & 4.337224 & 1.371091 & -0.855405 \\ \mathrm{H} & 3.619180 & -2.433847 & 0.531886 \\ \mathrm{C} & -0.770963 & 2.288482 & 1.072243 \\ \mathrm{H} & -1.224116 & 1.802654 & 1.928612 \\ \mathrm{H} & 0.250309 & 2.533373 & 1.331931 \\ \mathrm{H} & -1.296039 & 3.218601 & 0.896069 \\ \mathrm{H} & 1.312251 & -2.145125 & 0.716583\end{array}$


1-Z, CASSCF/cc-pVTZ, MEP point 3

$\begin{array}{rrrr}\mathrm{C} & 1.870134 & -1.260267 & 0.459674 \\ \mathrm{C} & 1.313678 & -0.133689 & -0.000733 \\ \mathrm{C} & 2.166233 & 0.975977 & -0.563730 \\ \mathrm{C} & -0.163095 & 0.045397 & -0.035806 \\ \mathrm{C} & -1.080787 & -0.961769 & 0.007131 \\ \mathrm{C} & -0.858315 & 1.395113 & -0.131551 \\ \mathrm{C} & -2.406341 & -0.463696 & -0.115853 \\ \mathrm{H} & -0.456178 & 1.965830 & -0.959147 \\ \mathrm{C} & -2.328417 & 1.006520 & -0.415537 \\ \mathrm{H} & -2.576371 & 1.168599 & -1.459727 \\ \mathrm{H} & -3.026248 & 1.588234 & 0.170724 \\ \mathrm{H} & -0.860787 & -2.006226 & 0.101613 \\ \mathrm{H} & 2.011811 & 1.881745 & 0.016666 \\ \mathrm{H} & 1.837105 & 1.226243 & -1.571306 \\ \mathrm{~N} & 3.270199 & -1.492163 & 0.382982 \\ \mathrm{C} & -3.572982 & -1.252085 & -0.017438 \\ \mathrm{H} & -3.436942 & -2.295039 & 0.203921 \\ \mathrm{C} & -4.841468 & -0.784905 & -0.196995 \\ \mathrm{H} & -5.043836 & 0.242066 & -0.428884 \\ \mathrm{H} & -5.684059 & -1.441317 & -0.114946 \\ \mathrm{C} & 4.085445 & -0.588386 & -0.118245 \\ \mathrm{H} & 5.126741 & -0.838628 & -0.157369 \\ \mathrm{C} & 3.614703 & 0.627725 & -0.585057 \\ \mathrm{H} & 4.316899 & 1.313317 & -1.011912 \\ \mathrm{H} & 3.628075 & -2.365562 & 0.692658 \\ \mathrm{C} & -0.736726 & 2.240577 & 1.140780 \\ \mathrm{H} & -1.177889 & 1.729803 & 1.988926 \\ \mathrm{H} & 0.292842 & 2.465300 & 1.387728 \\ \mathrm{H} & -1.255085 & 3.181588 & 1.008020 \\ \mathrm{H} & 1.320714 & -2.069627 & 0.888119\end{array}$


1-Z, CASSCF/cc-pVTZ, MEP point 4

$\begin{array}{lrrr}\mathrm{C} & 1.871419 & -1.207773 & 0.549236 \\ \mathrm{C} & 1.310307 & -0.129060 & -0.009161 \\ \mathrm{C} & 2.156026 & 0.937433 & -0.658114 \\ \mathrm{C} & -0.165399 & 0.044617 & -0.061904 \\ \mathrm{C} & -1.076458 & -0.967289 & -0.088437 \\ \mathrm{C} & -0.859734 & 1.396331 & -0.087213 \\ \mathrm{C} & -2.406273 & -0.465328 & -0.157044 \\ \mathrm{H} & -0.469844 & 1.994579 & -0.902170 \\ \mathrm{C} & -2.335955 & 1.022250 & -0.359760 \\ \mathrm{H} & -2.611630 & 1.254495 & -1.383476 \\ \mathrm{H} & -3.018989 & 1.560848 & 0.282504 \\ \mathrm{H} & -0.846534 & -2.013984 & -0.061580 \\ \mathrm{H} & 2.006754 & 1.878715 & -0.134756 \\ \mathrm{H} & 1.812356 & 1.122781 & -1.674928 \\ \mathrm{~N} & 3.269150 & -1.439272 & 0.481116 \\ \mathrm{C} & -3.571252 & -1.257133 & -0.074729 \\ \mathrm{H} & -3.431898 & -2.312344 & 0.074995 \\ \mathrm{C} & -4.843538 & -0.777604 & -0.182463 \\ \mathrm{H} & -5.050085 & 0.262401 & -0.341457 \\ \mathrm{H} & -5.685052 & -1.437191 & -0.116682 \\ \mathrm{C} & 4.079429 & -0.583055 & -0.108891 \\ \mathrm{H} & 5.119296 & -0.839560 & -0.141162 \\ \mathrm{C} & 3.603099 & 0.585836 & -0.674737 \\ \mathrm{H} & 4.297473 & 1.225789 & -1.178643 \\ \mathrm{H} & 3.632189 & -2.285049 & 0.855752 \\ \mathrm{C} & -0.702783 & 2.194814 & 1.210063 \\ \mathrm{H} & -1.125727 & 1.656733 & 2.050660 \\ \mathrm{H} & 0.334939 & 2.404252 & 1.437600 \\ \mathrm{H} & -1.217941 & 3.142943 & 1.124385 \\ \mathrm{H} & 1.323855 & -1.979190 & 1.045963\end{array}$


1-Z, CASSCF/cc-pVTZ, MEP point 5

$\begin{array}{rrrr}\mathrm{C} & 1.871000 & -1.147027 & 0.632801 \\ \mathrm{C} & 1.306211 & -0.122179 & -0.017454 \\ \mathrm{C} & 2.148166 & 0.892476 & -0.748937 \\ \mathrm{C} & -0.167874 & 0.047223 & -0.083273 \\ \mathrm{C} & -1.072530 & -0.965457 & -0.175763 \\ \mathrm{C} & -0.861545 & 1.396946 & -0.039665 \\ \mathrm{C} & -2.405611 & -0.464900 & -0.196540 \\ \mathrm{H} & -0.485851 & 2.021392 & -0.842624 \\ \mathrm{C} & -2.343441 & 1.034045 & -0.297913 \\ \mathrm{H} & -2.649472 & 1.338261 & -1.293544 \\ \mathrm{H} & -3.009322 & 1.521978 & 0.400555 \\ \mathrm{H} & -0.833131 & -2.009738 & -0.211059 \\ \mathrm{H} & 2.010337 & 1.865059 & -0.280234 \\ \mathrm{H} & 1.787927 & 1.019105 & -1.769321 \\ \mathrm{~N} & 3.264316 & -1.377001 & 0.575847 \\ \mathrm{C} & -3.568209 & -1.262154 & -0.136062 \\ \mathrm{H} & -3.425648 & -2.324822 & -0.060241 \\ \mathrm{C} & -4.842691 & -0.777648 & -0.176236 \\ \mathrm{H} & -5.052386 & 0.270358 & -0.259749 \\ \mathrm{H} & -5.682875 & -1.440645 & -0.131074 \\ \mathrm{C} & 4.072060 & -0.581065 & -0.102994 \\ \mathrm{H} & 5.109133 & -0.848837 & -0.127680 \\ \mathrm{C} & 3.592100 & 0.531054 & -0.764805 \\ \mathrm{H} & 4.277908 & 1.115085 & -1.342662 \\ \mathrm{H} & 3.630945 & -2.191973 & 1.011149 \\ \mathrm{C} & -0.668134 & 2.151210 & 1.277767 \\ \mathrm{H} & -1.068001 & 1.587032 & 2.112502 \\ \mathrm{H} & 0.376965 & 2.351238 & 1.480725 \\ \mathrm{H} & -1.182147 & 3.103021 & 1.238198 \\ \mathrm{H} & 1.324616 & -1.873055 & 1.195145\end{array}$


1-Z, CASSCF/cc-pVTZ, MEP point 6

$\begin{array}{rrrr}\mathrm{C} & 1.872012 & -1.076810 & 0.712173 \\ \mathrm{C} & 1.302210 & -0.114555 & -0.026129 \\ \mathrm{C} & 2.141084 & 0.838612 & -0.838644 \\ \mathrm{C} & -0.170203 & 0.052434 & -0.098768 \\ \mathrm{C} & -1.069290 & -0.956593 & -0.255673 \\ \mathrm{C} & -0.864009 & 1.397122 & 0.010827 \\ \mathrm{C} & -2.404790 & -0.461548 & -0.232582 \\ \mathrm{H} & -0.503534 & 2.046110 & -0.780708 \\ \mathrm{C} & -2.350785 & 1.041952 & -0.231671 \\ \mathrm{H} & -2.687642 & 1.415936 & -1.192776 \\ \mathrm{H} & -2.998124 & 1.474024 & 0.519383 \\ \mathrm{H} & -0.822163 & -1.995735 & -0.349022 \\ \mathrm{H} & 2.016075 & 1.840488 & -0.430515 \\ \mathrm{H} & 1.764450 & 0.902975 & -1.858797 \\ \mathrm{~N} & 3.258419 & -1.308290 & 0.661918 \\ \mathrm{C} & -3.564584 & -1.264934 & -0.200399 \\ \mathrm{H} & -3.418411 & -2.329892 & -0.198404 \\ \mathrm{C} & -4.840486 & -0.783442 & -0.177941 \\ \mathrm{H} & -5.054285 & 0.267082 & -0.186202 \\ \mathrm{H} & -5.678083 & -1.450938 & -0.157928 \\ \mathrm{C} & 4.064930 & -0.581902 & -0.099412 \\ \mathrm{H} & 5.098932 & -0.861069 & -0.112503 \\ \mathrm{C} & 3.581651 & 0.465564 & -0.850942 \\ \mathrm{H} & 4.259181 & 0.988279 & -1.493885 \\ \mathrm{H} & 3.628304 & -2.085459 & 1.160222 \\ \mathrm{C} & -0.635896 & 2.109873 & 1.344684 \\ \mathrm{H} & -1.009066 & 1.517945 & 2.172668 \\ \mathrm{H} & 0.414478 & 2.308203 & 1.522112 \\ \mathrm{H} & -1.154056 & 3.060125 & 1.351012 \\ \mathrm{H} & 1.326980 & -1.754514 & 1.333639\end{array}$


1-Z, CASSCF/cc-pVTZ, MEP point 7

$\begin{array}{rrrr}\mathrm{C} & 1.875585 & -0.998733 & 0.785412 \\ \mathrm{C} & 1.298575 & -0.105876 & -0.035419 \\ \mathrm{C} & 2.134586 & 0.774097 & -0.928283 \\ \mathrm{C} & -0.172114 & 0.059415 & -0.108353 \\ \mathrm{C} & -1.066525 & -0.942060 & -0.328706 \\ \mathrm{C} & -0.867490 & 1.396141 & 0.064948 \\ \mathrm{C} & -2.403866 & -0.455982 & -0.266114 \\ \mathrm{H} & -0.523192 & 2.068457 & -0.715311 \\ \mathrm{C} & -2.358141 & 1.045053 & -0.161882 \\ \mathrm{H} & -2.725531 & 1.486972 & -1.081774 \\ \mathrm{H} & -2.985593 & 1.415541 & 0.637895 \\ \mathrm{H} & -0.813225 & -1.973328 & -0.478112 \\ \mathrm{H} & 2.021069 & 1.803545 & -0.589997 \\ \mathrm{H} & 1.743572 & 0.769672 & -1.944793 \\ \mathrm{~N} & 3.251348 & -1.235106 & 0.737662 \\ \mathrm{C} & -3.560705 & -1.264879 & -0.265724 \\ \mathrm{H} & -3.411082 & -2.327155 & -0.335741 \\ \mathrm{C} & -4.837599 & -0.792408 & -0.187162 \\ \mathrm{H} & -5.055347 & 0.255372 & -0.122847 \\ \mathrm{H} & -5.672266 & -1.463810 & -0.194955 \\ \mathrm{C} & 4.059010 & -0.583591 & -0.097026 \\ \mathrm{H} & 5.089744 & -0.873598 & -0.094101 \\ \mathrm{C} & 3.572769 & 0.392023 & -0.930269 \\ \mathrm{H} & 4.242627 & 0.852797 & -1.626637 \\ \mathrm{H} & 3.625440 & -1.967430 & 1.298041 \\ \mathrm{C} & -0.607878 & 2.071620 & 1.411133 \\ \mathrm{H} & -0.952481 & 1.453660 & 2.232623 \\ \mathrm{H} & 0.445768 & 2.274958 & 1.563225 \\ \mathrm{H} & -1.133055 & 3.016731 & 1.459648 \\ \mathrm{H} & 1.332895 & -1.620848 & 1.464751\end{array}$


1-Z, CASSCF/cc-pVTZ, MEP point 8

$\begin{array}{rrrr}\mathrm{C} & 1.883400 & -0.914334 & 0.850693 \\ \mathrm{C} & 1.295144 & -0.095285 & -0.045919 \\ \mathrm{C} & 2.127967 & 0.697492 & -1.017571 \\ \mathrm{C} & -0.173366 & 0.067699 & -0.111934 \\ \mathrm{C} & -1.063956 & -0.922067 & -0.396495 \\ \mathrm{C} & -0.871962 & 1.394005 & 0.122078 \\ \mathrm{C} & -2.402605 & -0.448150 & -0.298056 \\ \mathrm{H} & -0.544519 & 2.087773 & -0.647545 \\ \mathrm{C} & -2.365418 & 1.043498 & -0.089974 \\ \mathrm{H} & -2.762677 & 1.550199 & -0.962403 \\ \mathrm{H} & -2.971726 & 1.347129 & 0.753304 \\ \mathrm{H} & -0.805068 & -1.942588 & -0.601042 \\ \mathrm{H} & 2.022925 & 1.751697 & -0.761389 \\ \mathrm{H} & 1.725332 & 0.614768 & -2.025658 \\ \mathrm{~N} & 3.242186 & -1.158793 & 0.804020 \\ \mathrm{C} & -3.556685 & -1.261710 & -0.330931 \\ \mathrm{H} & -3.403264 & -2.316737 & -0.469807 \\ \mathrm{C} & -4.834346 & -0.803367 & -0.201774 \\ \mathrm{H} & -5.056483 & 0.237045 & -0.068759 \\ \mathrm{H} & -5.665539 & -1.478066 & -0.238060 \\ \mathrm{C} & 4.055274 & -0.584729 & -0.096213 \\ \mathrm{H} & 5.082512 & -0.884006 & -0.071121 \\ \mathrm{C} & 3.565915 & 0.312334 & -1.001149 \\ \mathrm{H} & 4.229664 & 0.715366 & -1.738000 \\ \mathrm{H} & 3.619393 & -1.842481 & 1.422079 \\ \mathrm{C} & -0.585175 & 2.036090 & 1.478011 \\ \mathrm{H} & -0.903975 & 1.394066 & 2.291498 \\ \mathrm{H} & 0.470005 & 2.246977 & 1.608755 \\ \mathrm{H} & -1.117584 & 2.974397 & 1.564705 \\ \mathrm{H} & 1.342639 & -1.471046 & 1.586247\end{array}$


1-Z, CASSCF/cc-pVTZ, MEP point 9

$\begin{array}{rrrr}\mathrm{C} & 1.894871 & -0.825708 & 0.906479 \\ \mathrm{C} & 1.291964 & -0.082579 & -0.060321 \\ \mathrm{C} & 2.121364 & 0.609291 & -1.105733 \\ \mathrm{C} & -0.173173 & 0.077619 & -0.111932 \\ \mathrm{C} & -1.061843 & -0.897446 & -0.456694 \\ \mathrm{C} & -0.877432 & 1.391340 & 0.180975 \\ \mathrm{C} & -2.400739 & -0.438173 & -0.327113 \\ \mathrm{H} & -0.568744 & 2.106921 & -0.576860 \\ \mathrm{C} & -2.372539 & 1.037132 & -0.016853 \\ \mathrm{H} & -2.799624 & 1.603962 & -0.836063 \\ \mathrm{H} & -2.956437 & 1.270339 & 0.864386 \\ \mathrm{H} & -0.798471 & -1.904601 & -0.716024 \\ \mathrm{H} & 2.019339 & 1.683086 & -0.948712 \\ \mathrm{H} & 1.711185 & 0.434062 & -2.098166 \\ \mathrm{~N} & 3.229650 & -1.081536 & 0.861820 \\ \mathrm{C} & -3.552427 & -1.255149 & -0.395521 \\ \mathrm{H} & -3.395290 & -2.298917 & -0.600916 \\ \mathrm{C} & -4.830595 & -0.815134 & -0.220898 \\ \mathrm{H} & -5.057535 & 0.213643 & -0.021530 \\ \mathrm{H} & -5.657926 & -1.492308 & -0.286829 \\ \mathrm{C} & 4.053743 & -0.584252 & -0.096414 \\ \mathrm{H} & 5.078012 & -0.887317 & -0.041356 \\ \mathrm{C} & 3.561993 & 0.229276 & -1.062516 \\ \mathrm{H} & 4.221671 & 0.581121 & -1.829038 \\ \mathrm{H} & 3.612280 & -1.706099 & 1.537785 \\ \mathrm{C} & -0.567833 & 2.001693 & 1.545330 \\ \mathrm{H} & -0.860974 & 1.336041 & 2.349677 \\ \mathrm{H} & 0.487131 & 2.224937 & 1.657884 \\ \mathrm{H} & -1.109938 & 2.930339 & 1.668108 \\ \mathrm{H} & 1.354334 & -1.308179 & 1.693463\end{array}$


1-Z, CASSCF/cc-pVTZ, MEP point 10

$\begin{array}{rrrr}\mathrm{C} & 1.906902 & -0.739153 & 0.947008 \\ \mathrm{C} & 1.288616 & -0.069411 & -0.079766 \\ \mathrm{C} & 2.113611 & 0.511559 & -1.191489 \\ \mathrm{C} & -0.171822 & 0.090069 & -0.109629 \\ \mathrm{C} & -1.061504 & -0.872058 & -0.497664 \\ \mathrm{C} & -0.883310 & 1.390199 & 0.237509 \\ \mathrm{C} & -2.399073 & -0.426728 & -0.348526 \\ \mathrm{H} & -0.598756 & 2.130856 & -0.505330 \\ \mathrm{C} & -2.379516 & 1.026712 & 0.058709 \\ \mathrm{H} & -2.840807 & 1.646108 & -0.701056 \\ \mathrm{H} & -2.935277 & 1.187335 & 0.974197 \\ \mathrm{H} & -0.794508 & -1.865151 & -0.804590 \\ \mathrm{H} & 2.009777 & 1.595532 & -1.153021 \\ \mathrm{H} & 1.699600 & 0.227575 & -2.156177 \\ \mathrm{~N} & 3.219889 & -0.999375 & 0.913359 \\ \mathrm{C} & -3.549440 & -1.243545 & -0.463064 \\ \mathrm{H} & -3.388004 & -2.271245 & -0.736201 \\ \mathrm{C} & -4.828247 & -0.825731 & -0.249446 \\ \mathrm{H} & -5.060300 & 0.186141 & 0.019046 \\ \mathrm{H} & -5.651650 & -1.503135 & -0.351850 \\ \mathrm{C} & 4.054990 & -0.580223 & -0.094760 \\ \mathrm{H} & 5.078391 & -0.875780 & -0.004897 \\ \mathrm{C} & 3.558689 & 0.144335 & -1.116651 \\ \mathrm{H} & 4.216409 & 0.447535 & -1.905508 \\ \mathrm{H} & 3.609668 & -1.551592 & 1.647345 \\ \mathrm{C} & -0.552011 & 1.964470 & 1.612071 \\ \mathrm{H} & -0.818064 & 1.271475 & 2.402893 \\ \mathrm{H} & 0.501534 & 2.203105 & 1.708355 \\ \mathrm{H} & -1.105230 & 2.880339 & 1.775162 \\ \mathrm{H} & 1.366473 & -1.141880 & 1.778253\end{array}$


1-Z, CASSCF/cc-pVTZ, MEP point 11

$\begin{array}{lrrc}\mathrm{C} & 1.921522 & -0.667482 & 0.970456 \\ \mathrm{C} & 1.285113 & -0.068413 & -0.099055 \\ \mathrm{C} & 2.097456 & 0.406104 & -1.268725 \\ \mathrm{C} & -0.171762 & 0.096647 & -0.100174 \\ \mathrm{C} & -1.066966 & -0.860873 & -0.495014 \\ \mathrm{C} & -0.886222 & 1.387227 & 0.287128 \\ \mathrm{C} & -2.401294 & -0.418166 & -0.347482 \\ \mathrm{H} & -0.628829 & 2.151068 & -0.441336 \\ \mathrm{C} & -2.384256 & 1.012673 & 0.137840 \\ \mathrm{H} & -2.883817 & 1.670911 & -0.562127 \\ \mathrm{H} & -2.904038 & 1.108983 & 1.083752 \\ \mathrm{H} & -0.800693 & -1.845024 & -0.831156 \\ \mathrm{H} & 1.978294 & 1.484588 & -1.360195 \\ \mathrm{H} & 1.683305 & 0.002465 & -2.189390 \\ \mathrm{~N} & 3.226618 & -0.905697 & 0.954480 \\ \mathrm{C} & -3.552827 & -1.222625 & -0.534026 \\ \mathrm{H} & -3.386938 & -2.231298 & -0.868980 \\ \mathrm{C} & -4.834284 & -0.820191 & -0.313108 \\ \mathrm{H} & -5.071119 & 0.171423 & 0.019560 \\ \mathrm{H} & -5.655388 & -1.489569 & -0.471450 \\ \mathrm{C} & 4.061169 & -0.558450 & -0.093689 \\ \mathrm{H} & 5.089154 & -0.825006 & 0.026017 \\ \mathrm{C} & 3.550145 & 0.068604 & -1.166463 \\ \mathrm{H} & 4.202494 & 0.326341 & -1.975839 \\ \mathrm{H} & 3.629707 & -1.375673 & 1.737868 \\ \mathrm{C} & -0.529079 & 1.924064 & 1.671096 \\ \mathrm{H} & -0.764400 & 1.201502 & 2.445348 \\ \mathrm{H} & 0.522510 & 2.178901 & 1.748935 \\ \mathrm{H} & -1.092870 & 2.824374 & 1.879061 \\ \mathrm{H} & 1.387608 & -1.000383 & 1.836260\end{array}$


1-Z, CASSCF/cc-pVTZ, MEP point 12

$\begin{array}{rrrr}\text { C } & 1.953698 & -0.628125 & 0.991390 \\ \mathrm{C} & 1.281390 & -0.095611 & -0.093778 \\ \mathrm{C} & 2.058041 & 0.311948 & -1.312473 \\ \mathrm{C} & -0.174510 & 0.068351 & -0.060865 \\ \mathrm{C} & -1.079839 & -0.884980 & -0.445819 \\ \mathrm{C} & -0.879587 & 1.365675 & 0.325444 \\ \mathrm{C} & -2.408465 & -0.423589 & -0.322688 \\ \mathrm{H} & -0.628955 & 2.128281 & -0.406461 \\ \mathrm{C} & -2.380802 & 0.995987 & 0.194869 \\ \mathrm{H} & -2.895696 & 1.673460 & -0.474410 \\ \mathrm{H} & -2.879124 & 1.065400 & 1.155029 \\ \mathrm{H} & -0.822203 & -1.870673 & -0.784261 \\ \mathrm{H} & 1.895747 & 1.371414 & -1.500785 \\ \mathrm{H} & 1.645399 & -0.190223 & -2.184400 \\ \mathrm{~N} & 3.263369 & -0.818933 & 0.969269 \\ \mathrm{C} & -3.567810 & -1.194374 & -0.590129 \\ \mathrm{H} & -3.407514 & -2.196502 & -0.946923 \\ \mathrm{C} & -4.849449 & -0.767230 & -0.426671 \\ \mathrm{H} & -5.081290 & 0.219001 & -0.074907 \\ \mathrm{H} & -5.675889 & -1.411170 & -0.649711 \\ \mathrm{C} & 4.073074 & -0.503250 & -0.111081 \\ \mathrm{H} & 5.111984 & -0.721353 & 0.011712 \\ \mathrm{C} & 3.524326 & 0.036183 & -1.211359 \\ \mathrm{H} & 4.156236 & 0.272253 & -2.043311 \\ \mathrm{H} & 3.694583 & -1.222239 & 1.774854 \\ \mathrm{C} & -0.504620 & 1.899606 & 1.706264 \\ \mathrm{H} & -0.725986 & 1.172725 & 2.480631 \\ \mathrm{H} & 0.546951 & 2.158616 & 1.769627 \\ \mathrm{H} & -1.068794 & 2.796714 & 1.926930 \\ \mathrm{H} & 1.444031 & -0.924451 & 1.884821\end{array}$


1-Z, CASSCF/cc-pVTZ, MEP point 13

$\begin{array}{rrrr}\text { C } & 2.000161 & -0.608089 & 1.017785 \\ \mathrm{C} & 1.277827 & -0.134741 & -0.062459 \\ \mathrm{C} & 2.001222 & 0.236892 & -1.325021 \\ \mathrm{C} & -0.177390 & 0.020527 & 0.008501 \\ \mathrm{C} & -1.092506 & -0.925369 & -0.374207 \\ \mathrm{C} & -0.868642 & 1.335684 & 0.358805 \\ \mathrm{C} & -2.413798 & -0.435316 & -0.295272 \\ \mathrm{H} & -0.603636 & 2.077633 & -0.389437 \\ \mathrm{C} & -2.372860 & 0.982994 & 0.224530 \\ \mathrm{H} & -2.880302 & 1.669156 & -0.441285 \\ \mathrm{H} & -2.870802 & 1.052294 & 1.185186 \\ \mathrm{H} & -0.845287 & -1.917538 & -0.701349 \\ \mathrm{H} & 1.787347 & 1.275183 & -1.568704 \\ \mathrm{H} & 1.585440 & -0.333153 & -2.152728 \\ \mathrm{~N} & 3.314978 & -0.751201 & 0.961349 \\ \mathrm{C} & -3.579482 & -1.168169 & -0.634014 \\ \mathrm{H} & -3.430729 & -2.176116 & -0.979130 \\ \mathrm{C} & -4.852817 & -0.694049 & -0.562186 \\ \mathrm{H} & -5.072831 & 0.301124 & -0.228368 \\ \mathrm{H} & -5.684397 & -1.308770 & -0.841448 \\ \mathrm{C} & 4.081114 & -0.444174 & -0.153171 \\ \mathrm{H} & 5.131392 & -0.612987 & -0.051532 \\ \mathrm{C} & 3.480069 & 0.028173 & -1.256647 \\ \mathrm{H} & 4.078138 & 0.259031 & -2.114649 \\ \mathrm{H} & 3.785349 & -1.104377 & 1.768453 \\ \mathrm{C} & -0.495813 & 1.897289 & 1.729082 \\ \mathrm{H} & -0.729372 & 1.190492 & 2.518164 \\ \mathrm{H} & 0.558310 & 2.145993 & 1.792439 \\ \mathrm{H} & -1.050894 & 2.805639 & 1.925859 \\ \mathrm{H} & 1.529622 & -0.884458 & 1.938621\end{array}$

